\title{
PENGARUH PEMBERIAN MAKANAN PENDAMPING AIR SUSU IBU (MP-ASI) FORMULA TEMPE TERHADAP DIARE, AKTIVITAS FISIK, DAN PERTUMBUHAN, BAYI STATUS GIZI BAIK USIA 6 - 12 BULAN DI BOGOR JAWA BARAT
}

\author{
Arum Atmawikarta ${ }^{1}$ \\ ${ }^{1}$ Badan Perencanaan Pembangunan Nasional, Jakarta
}

\begin{abstract}
THE IMPACT OF TEMPE (FERMENTED SOYBEAN) BASED COMPLEMENTARY FOOD FORMULA ON DIARHEA, PHYSICAL ACTIVITY AND GROWTH AMONG 6-12 YEARS OLD CHILDREN IN BOGOR, WEST JAVA

\begin{abstract}
Malnutrition is prevalent in developing countries including Indonesia. In more than 100 districts in Indonesia, children under five years old suffered from underweight (WAZ) at least 30 percent. Complementary food has beneficial for the children in preventing determinative condition. However, home made complementary food lack of micronutrients such as vitamin A, iron and zinc. Complementary food based on fermented soybean (tempe), coconut oil and skimmed milk so called tempe formula, has distinctive effect in improving nutritional status and recovering diarhea effectively among malnourished children. However, the effect of tempe formula on morbidity of diarhea, physical activity and growth of healthy children has not been recognized yet. This study consisted of 144 six-month old infants (SD \pm 15 days) who was divided into two groups (72 infants each) in a double blinded RCT. One group is allocated to receive tempe formula (FT) and the other group receive non-tempe complementary food (FBT). After five-month intervention, at the endline, there were 49 infants in FT group and 45 infants in non FT (FBT). During the study the energy consumption of the infants increased according to age. The proportion of energy consumption was about 27 to 46 percent of RDA and there was no significant difference between two groups. The number of diarhea was fluctuative in the two groups, in cumulative number was 2 or 3 episodes in both groups. There was no significant difference in number of diarhea episode between the two groups and so the length of the episode (between 8 and 10 days). There was also no difference in physical activity and motoric development and growth achievement between two groups. The weight for height z-score of infants has decrease in both group. In conclusion, the study failed to show the benefical of tempe formula for healthy infants age 6-12 months in the episode and length of diarhea growth and in physical activity but showed significant improvement of ferritin level.
\end{abstract}

Keywords: complementary food, tempe, growth physical activity, children, fermented soybean

\section{PENDAHULUAN}

S alah satu indikator rendahnya status gizi masyarakat adalah tingginya prevalensi gizi kurang, terutama pada bayi umur 6-23 bulan. Pada tahun 2000, prevalensi gizi kurang (Z-score berat badan menurut umur kurang dari -2 standar deviasi) pada anak balita di negara-negara berkembang diperkirakan sebesar 27 persen ${ }^{(1)}$. Data Statistik Kesehatan tahun 2001 menunjukkan prevalensi gizi kurang pada anak balita di Indonesia sekitar 30,2 persen ${ }^{(2)}$. Pada tahun 2003, lebih dari 100 kabupaten/ kota mempunyai prevalensi gizi kurang di atas 30 persen. 
Gizi Indon 2007,30(2):73-97 Pengaruh pemberian makanan Arum

Atmawikarta

Analisis data Susenas tahun 1989-1999 menunjukkan bahwa gangguan pertumbuhan telah mulai terjadi pada saat bayi berusia 3 atau 4 bulan baik di perdesaan maupun di perkotaan. Menurunnya status gizi bayi sejak umur 4 bulan antara lain disebabkan oleh kebutuhan gizi bayi tidak dapat dipenuhi hanya dengan pemberian ASI saja ${ }^{(3)}$. Gangguan pertumbuhan (gagal tumbuh) pada umumnya mulai terjadi pada saat diperkenalkannya MP-ASI, yaitu pada umur 6 bulan, dan prevalensi gizi kurang pada umumnya akan terus meningkat pada umur 12-23 bulan disertai dengan penyakit infeksi, yang akhirnya meningkatkan risiko kematian bayi dan balita.

Pemberian ASI dan MP-ASI yang cukup nilai gizinya berperan terhadap pencegahan kematian bayi. Data WHO dan UNICEF (2003) menunjukkan, hanya sekitar 35 persen bayi di seluruh dunia menyusui eksklusif selama 4 bulan pertama ${ }^{(4)}$. Sejak umur 6 bulan diperlukan makanan padat pelengkap ASI yang dikenal sebagai makanan pendamping ASI (MP-ASI). Syarat MP-ASI yang baik adalah mengandung cukup zat gizi, aman dari segi kesehatan, dan terjangkau dari segi ekonomi. Saat ini, MP-ASI yang dibuat di rumah tidak dapat mencukupi kebutuhan zat gizi mikro terutama vitamin $A$, zat besi, dan seng ${ }^{(5)}$. Kebiasaan pemberian MP-ASI juga belum sesuai dengan pola yang dianjurkan.

Di pasaran tersedia MP-ASI produksi pabrik, namun harganya kurang terjangkau golongan masyarakat miskin. Kebijakan pemerintah mengenai MP-ASI yang ditujukan bagi bayi dan anak 6-24 bulan adalah untuk meningkatkan promosi MP-ASI yang memenuhi standar dan syarat kesehatan, mendorong produksi MP-ASI buatan rumah tangga (local fortified blended food) agar terjangkau oleh seluruh lapisan masyarakat, pendidikan gizi, dan konseling bagi semua calon ibu.

Pusat Penelitian dan Pengembangan Gizi dan Makanan, Departemen Kesehatan $\mathrm{RI}$, telah mengembangkan MP-ASI formula tempe sebagai MP-ASI dengan kandungan energi, protein, lemak, zat besi, kalsium, fosfor, dan vitamin $E$ yang sesuai dengan kebutuhan gizi bayi dengan harga yang terjangkau. Beberapa penelitian tentang MPASI formula tempe telah dilakukan. Mahmud (1987) menunjukkan keunggulan MP-ASI formula tempe dari segi komposisi zat gizi, dan perannya untuk mengurangi sensitifitas enteropati protein dan intoleransi karbohidrat ${ }^{(6)}$. MP-ASI formula tempe juga membantu menghentikan proses peradangan atau infeksi saluran cerna pada bayi umur 6-24 bulan ${ }^{(7)}$, efektif bagi penyembuhan diare ${ }^{(6)}$, dan memperbaiki keadaan gizi penderita. Walaupun penelitian tentang MPASI formula tempe menunjukkan berbagai keunggulan khususnya dalam penyembuhaan diare, namun pengaruhnya terhadap morbiditas diare, aktivitas fisik, gerak motorik kasar, dan pertumbuhan, belum diketahui khususnya pada bayi dengan status gizi baik. Penelitian ini mengkaji pengaruh MPASI formula tempe terhadap morbiditas diare, aktivitas fisik, gerak motorik kasar, dan tingkat pertumbuhan.

Pertanyaan yang dijawab pada penelitian ini adalah: "Apakah pemberian MP-ASI formula tempe dapat menurunkan morbiditas diare, meningkatkan aktivitas fisik, mempercepat gerak motorik kasar, dan meningkatkan pertumbuhan bayi umur 6-12 bulan dengan status gizi baik?" Jawaban dari pertanyaan ini diperlukan untuk memberikan alternatif bagi pemerintah dalam merumuskan kebijakan pemberian MP-ASI yang lebih efektif dan murah.

\section{Tujuan}

Tujuan umum penelitian ini adalah mempelajari pengaruh MP-ASI formula tempe terhadap morbiditas diare, aktivitas fisik, gerak motorik kasar, dan tingkat pertumbuhan. Secara khusus, tujuan penelitian ini adalah mempelajari perbedaan tingkat morbiditas, aktivitas fisik, gerak motorik kasar, dan pertumbuhan bayi umur 6-12 bulan dengan status gizi baik yang mendapat MP-ASI formula tempe (FT) dan bayi yang mendapat MP-ASI formula bukan tempe (FBT).

Berbagai penelitian yang telah dilakukan membuktikan bahwa pemberian 
MP-ASI berbasis tempe memiliki kemampuan untuk mengurangi lama waktu diare pada bayi di atas 6 bulan yang menderita diare dengan status gizi kurang. Pemberian MP-ASI Formula Tempe (FT) secara cukup diharapkan dapat mengurangi morbiditas diare, meningkatkan kadar zat gizi mikro dalam darah, dan dapat menjaga pertumbuhan anak.

Berbagai faktor dapat mempengaruhi morbiditas dan pertumbuhan serta aktivitas fisik anak, adalah tingkat pendidikan orang tua, pekerjaan orangtua, kondisi ekonomi orangtua, keadaaan sanitasi lingkungan, makanan lain selain MP-ASI, dan kondisi lingkungan sosial. Oleh karena itu, pada penelitian ini, faktor-faktor yang mempengaruhi morbiditas dan pertumbuhan dan aktifitas fisik anak diperhatikan.

Peubah tergantung (dependent variables) yang diteliti adalah diare, aktivitas fisik, gerak motorik kasar, dan pertumbuhan.
Peubah bebas (independent variables) adalah jenis MP-ASI, yang terdiri dari MPASI Formula Tempe (FT) dan MP-ASI Formula Bukan Tempe (FBT). Sedangkan peubah perancu (confounders) meliputi tingkat pendidikan orangtua, pekerjaan orangtua, tingkat pendapatan orang tua, konsumsi makanan bayi selain MP-ASI, kadar zat gizi mikro dalam darah, kunjungan ke Posyandu, sumber air minum, dan ketersediaan jamban.

Untuk menjawab tujuan penelitian di atas, kerangka konsep yang digunakan tertera pada Gambar 1. Penelitian ini menggunakan desain eksperimen murni teracak buta ganda (Double Blind Randomized Controlled Trial) dengan sampel bayi sebagai unit alokasi perlakuan acak dan merupakan penelitian longitudinal, mengikuti sampel yang sama selama 5 bulan.

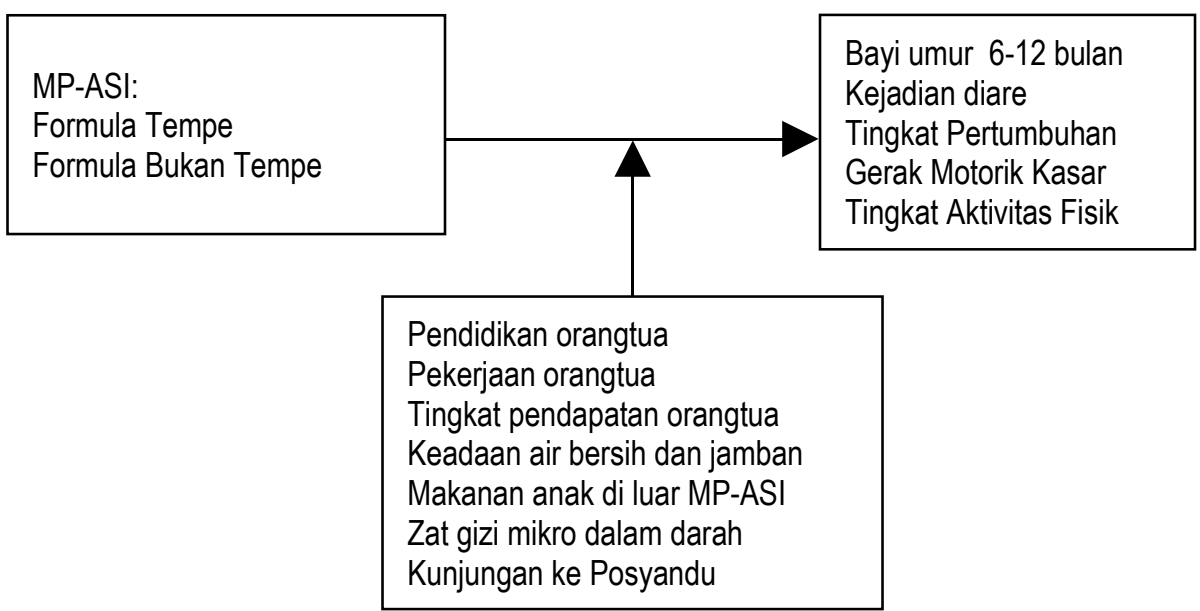

\section{METODOLOGI}

Populasi penelitian ini adalah bayi umur 6 bulan. Sampel penelitian adalah bayi umur 6 bulan pada rekruitmen yang memenuhi persyaratan inklusi. Unit observasi adalah keluarga dan bayi, sedangkan unit analisisnya adalah bayi. Kriteria inklusi dalam pemilihan sampel adalah: bayi berusia 6 bulan \pm 15 hari pada saat rekrutmen; Zscore PB/U dan BB/PB antara -1 SD dan +1 $\mathrm{SD}$ (termasuk dalam kategori gizi baik), masih diberi ASI; tidak menderita penyakit TB paru dan penyakit kronis lain (menahun) dan tidak menderita kelainan bawaan; dan orangtua bersedia mengikutkan anaknya dalam penelitian sampai selesai. Pengambilan sampel dan penentuan perlakuan ditentukan berdasarkan Cohen (1977), yaitu dengan df $(6-1)^{\star}(2-1)=5$, dengan power uji 80 persen $(\beta=0,8)$ pada $\alpha$ $=0,05$ dan perkiraan effect size yang moderate, yaitu 0,25 maka diperlukan minimum jumlah sampel sebesar 35 bayi per 
Gizi Indon 2007,30(2):73-97 Pengaruh pemberian makanan Arum

kelompok $^{(8)}$. Dengan perhitungan lost of follow up sebesar 20 persen, maka jumlah sampel yang diperlukan sebanyak 42 bayi per kelompok.

Penelitian dilakukan di Kecamatan Bogor Barat dan Kecamatan Tanah Sareal, Kota Bogor, Jawa Barat, selama 12 bulan dari bulan Desember 2005 sampai dengan November 2006. Setiap data yang diperoleh diperiksa kelengkapan serta konsistensinya. Analisis univariat dilakukan terhadap setiap peubah yang dikumpulkan. Analisis bivariate dilakukan untuk mempelajari hubungan antara satu peubah dengan peubah lain. Analisis korelasi dan tabel kontingensi atau chi-square digunakan untuk menentukan peubah yang masuk dalam model untuk analisis multivariat. Analisis multivariat yang digunakan adalah GLM-Repeated Measures Analysis of Covariance untuk menilai pengaruh FT dan FBT terhadap diare, aktivitas fisik, gerak motorik kasar, dan pertumbuhan setelah mengontrol pengaruh peubah perancu.

Penelitian ini telah mendapat persetujuan dari Komisi Etik Penelitian Kesehatan, Badan Litbang Kesehatan, Departemen Kesehatan. Informed consent untuk orangtua subyek dibuat secara tertulis dan dibacakan kepada setiap orangtua yang anaknya memenuhi ketentuan sebagai calon sampel sebagai bagian dari proses screening untuk memperoleh persetujuan anaknya dilibatkan sebagai sampel penelitian.

\section{HASIL}

Jumlah bayi pada saat penelitian dimulai adalah 72 bayi pada kelompok FT dan dan 71 bayi pada kelompok FBT. Selama penelitian, jumlah bayi yang dropout adalah 24 bayi $(30.13 \%)$ pada kelompok FT dan 25 bayi (34.2\%) pada kelompok FBT sehingga sampel yang mengikuti penelitian sampai akhir penelitian menjadi 49 bayi pada kelompok FT dan 45 bayi pada kelompok
FBT. Jumlah sampel yang diperlukan selama penelitian masih memenuhi kecukupan sesuai kriteria. Uji beda-t dan uji proporsi menunjukkan tidak terdapat perbedaan yang bermakna $(p>0,05)$ pada karakteristik sampel bayi drop-out dan bayi yang tidak drop-out. Dilihat dari karakteristik sosial ekonomi sampel pada kedua kelompok, data dasar antropometri, dan zat gizi mikro dalam darah pada awal penelitian, tidak terdapat perbedaan secara bermakna antar kedua kelompok $(p>0,05)$.

Jumlah FT dan FBT yang diberikan kepada masing-masing kelompok didesain untuk memberi kontribusi bagi kecukupan energi sekitar 30 persen dari angka kecukupan gizi (AKG). Diperkirakan bahwa MP-ASI yang akan dikonsumsi bayi sebesar 80 persen dari jumlah yang diberikan pada umur 7, 8 dan 9 bulan; dan 70 persen pada umur 10 dan 11 bulan. Analisis menunjukkan bahwa rerata kepatuhan mengkonsumsi MPASI FT mencapai 81,8 persen, dan untuk FBT mencapai 80,1 persen. Tidak ada perbedaan kepatuhan antara FT dan FBT ( $p>0,05)$. Dengan demikian, sampel memiliki tingkat kepatuhan yang cukup tinggi terhadap konsumsi MP-ASI seperti yang diharapkan.

Asupan zat gizi pada sampel bayi dihitung dari MP-ASI perlakuan dan makanan selain MP-ASI yang diberikan ibu kepada bayi dengan menggunakan Daftar Komposisi Bahan Makanan yang telah tersedia dalam software Nutrisoft. Tabel 1 menunjukkan rerata asupan energi dari MPASI perlakuan, dimana jumlah MP-ASI yang diberikan kepada bayi cukup untuk melengkapi jumlah energi yang dibutuhkan bayi di luar energi yang diperoleh dari air susu ibu (ASI) dan makanan lain selain MP. ASI. Uji statistik GLM Repeated Measure Analysis of Covariance menunjukkan tidak ada perbedaan bermakna $(p>0,05)$ antara kedua kelompok tersebut dalam hal asupan energi dari MP-ASI. 
Tabel 1

Rerata Asupan Energi dari MP-ASI

\begin{tabular}{|c|c|c|c|c|c|c|c|}
\hline \multirow{2}{*}{$\begin{array}{c}\text { Umur } \\
\text { (bulan) }\end{array}$} & \multicolumn{2}{|c|}{ FT } & \multicolumn{3}{|c|}{ FBT } & \\
\cline { 2 - 6 } & $\mathrm{n}$ & $\begin{array}{c}\text { Rerata asupan energi } \\
\text { per hari (\% AKG) }\end{array}$ & $\mathrm{SD}$ & $\mathrm{n}$ & $\begin{array}{c}\text { Rerata asupan energi } \\
\text { per hari (\% AKG) }\end{array}$ & $\mathrm{SD}$ & $\mathrm{p}$ \\
\hline 6 & - & - & & - & - & - & - \\
7 & 49 & 27,4 & 7,20 & 45 & 26,5 & 5,39 & \\
8 & 49 & 27,7 & 8,41 & 45 & 26,9 & 5,63 & 0,950 \\
9 & 49 & 37,6 & 8,28 & 45 & 36,6 & 8,86 & 0,938 \\
10 & 49 & 35,0 & 11,89 & 45 & 34,2 & 11,09 & 0,989 \\
11 & 49 & 46,8 & 14,35 & 45 & 42,2 & 16,62 & 0,123 \\
\hline
\end{tabular}

Tabel 2 menunjukkan rerata asupan energi dari MP-ASI dan makanan selain MPASI. Asupan energi meningkat seiring dengan meningkatnya umur. Selama bulan perlakuan tersebut, asupan energi dari MPASI dan makanan selain MP-ASI antara kedua kelompok tidak berbeda secara bermakna $(p>0,05)$. Tabel 3 menunjukkan asupan protein pada bayi yang berasal dari MP-ASI perlakuan yang diberikan kepada bayi yaitu FT dan FBT. Pada umur 6 bulan, MP-ASI perlakuan (FT dan FBT) belum diberikan kepada bayi, sehingga tidak ada asupan protein dari MP-ASI. Pada umur 7 hingga 11 bulan, asupan protein dari MP-ASI berkisar antara 41,6 persen AKG (umur 7 bulan) hingga 71,0 persen (umur 11 bulan) AKG pada kelompok $\mathrm{FT}$, dan 27,5 persen (umur 7 bulan) hingga 43,6 persen AKG (umur 11 bulan) pada kelompok FBT.

Tabel 2

Asupan Energi dari MP-ASI dan Makanan Selain MP-ASI

\begin{tabular}{|c|c|c|c|c|c|c|c|}
\hline \multirow{2}{*}{$\begin{array}{c}\text { Umur } \\
\text { (bulan) }\end{array}$} & $\mathrm{n}$ & $\begin{array}{c}\text { Rerata asupan energi } \\
\text { per hari (\% AKG) }\end{array}$ & $\mathrm{SD}$ & $\mathrm{n}$ & $\begin{array}{c}\text { Rerata asupan energi } \\
\text { per hari (\% AKG) }\end{array}$ & $\mathrm{SD}$ & $\mathrm{p}$ \\
\hline 6 & 49 & 19,7 & 15,35 & 45 & 16,1 & 15,98 & \\
7 & 49 & 57,9 & 30,42 & 45 & 59,9 & 34,06 & 0,342 \\
8 & 49 & 66,7 & 35,76 & 45 & 60,7 & 31,60 & 0,334 \\
9 & 49 & 82,4 & 36,34 & 45 & 74,5 & 26,80 & 0,312 \\
10 & 49 & 83,8 & 38,66 & 45 & 79,3 & 32,66 & 0,920 \\
11 & 49 & 95,9 & 49,65 & 45 & 96,5 & 50,86 & 0,548 \\
\hline
\end{tabular}

Tabel 3

Asupan Protein dari MP-ASI

\begin{tabular}{|c|c|c|c|c|c|c|c|}
\hline \multirow{2}{*}{$\begin{array}{c}\text { Umur } \\
\text { (bulan) }\end{array}$} & $\mathrm{n}$ & $\begin{array}{c}\text { Rerata asupan protein } \\
\text { per hari (\% AKG) }\end{array}$ & $\mathrm{SD}$ & $\mathrm{n}$ & $\begin{array}{c}\text { Rerata asupan protein } \\
\text { per hari (\% AKG) }\end{array}$ & $\mathrm{SD}$ & $\mathrm{p}$ \\
\cline { 2 - 7 } & & - & - & - & - & - & \\
7 & 49 & 41,6 & 10,93 & 45 & 27,5 & 5,57 & \\
8 & 49 & 42,0 & 12,76 & 45 & 27,8 & 5,83 & 0,951 \\
9 & 49 & 57,0 & 12,57 & 45 & 37,9 & 9,17 & 0,022
\end{tabular}


Gizi Indon 2007,30(2):73-97 Pengaruh pemberian makanan Arum

Atmawikarta

\begin{tabular}{|l|l|l|l|l|l|l|l|}
10 & 49 & 53,1 & 18,04 & 45 & 35,3 & 11,48 & 0,430 \\
11 & 49 & 71,0 & 21,78 & 45 & 43,6 & 17,20 & 0,001 \\
\hline
\end{tabular}

Secara umum, pada kedua kelompok, asupan protein dari MP-ASI cenderung bermakna antara asupan zat besi dari MPmeningkat seiring dengan meningkatnya umur bayi. Uji GLM Repeated Measures Analysis of Covariance menunjukkan bahwa asupan protein pada kedua kelompok tidak berbeda bermakna $(p>0.05)$, kecuali pada umur 9 bulan di mana asupan protein pada kelompok FT rerata lebih besar 3,4 persen daripada kelompok FBT $(p=0,022)$ dan pada umur 11 bulan, asupan protein dari MP-ASI pada kelompok FBT rerata lebih besar 26,4 persen dari pada kelompok FT ( $p=0,001)$.

Asupan vitamin A yang berasal dari MP. ASI pada kedua kelompok mengalami peningkatan sejalan dengan bertambahnya umur bayi (Tabel 4). Asupan vitamin A pada kedua kelompok terus meningkat. Secara statistik tidak ada perbedaan bermakna asupan protein dari MP-ASI pada kedua kelompok $(p>0,05)$. Sedangkan tabel 5 menunjukkan data asupan zat besi dari MPASI yang terlihat mengalami peningkatan dari bulan ke bulan. Tidak ada perbedaan

ASI antara kedua kelompok $(p>0,05)$ Jumlah episode diare yang dialami bayi cukup berfluktuasi selama masa intervensi. Pada umur 6 bulan (data dasar) kejadian diare untuk kelompok FT adalah 0,24 kali diare per bulan dan untuk kelompok FBT sebanyak 0,27 kali per bulan. Jumlah ini kemudian meningkat dan berfluktuasi sepanjang 5 bulan masa intervensi (Tabel 6). Uji statistik GLM Repeated Measures Analysis of Covariance menunjukkan tidak ada perbedaan bermakna antara rerata jumlah episode diare antara kedua kelompok $(p>0,05)$

Untuk melihat apakah ada peningkatan/ penurunan episode diare selama 5 bulan masa perlakuan, dan jumlah kejadian diare selama masa penelitian dilakukan analisis terhadap kumulatif jumlah rerata episode per bulan. Tabel 7 menunjukkan kecenderungan kumulatif rerata jumlah episode diare per bulan pada kedua kelompok.

Tabel 4

Asupan Vitamin A dari MP-ASI

\begin{tabular}{|c|c|c|c|c|c|c|c|}
\hline \multirow{2}{*}{$\begin{array}{c}\text { Umur } \\
\text { (bulan) }\end{array}$} & $\mathrm{n}$ & $\begin{array}{c}\text { Rerata asupan } \\
\text { Vitamin A per hari } \\
\text { (\% AKG) }\end{array}$ & $\mathrm{SD}$ & $\mathrm{n}$ & $\begin{array}{c}\text { Rerata asupan } \\
\text { Vitamin A per hari } \\
(\% \text { AKG) }\end{array}$ & $\mathrm{SD}$ & $\mathrm{p}$ \\
\hline 6 & 49 & - & - & 45 & - & - & \\
7 & 49 & 33,0 & 8,66 & 45 & 31,9 & 6,48 & \\
8 & 49 & 33,3 & 10,10 & 45 & 32,4 & 6,78 & 0,950 \\
9 & 49 & 45,2 & 9,96 & 45 & 44,02 & 10,66 & 0,942 \\
10 & 49 & 42,1 & 14,29 & 45 & 41,09 & 13,34 & 0,988 \\
11 & 49 & 56,3 & 17,26 & 45 & 50,73 & 20,00 & 0,124 \\
\hline
\end{tabular}


Gizi Indon 2007,30(2):73-97 Pengaruh pemberian makanan Arum

Tabel 5

Asupan Zat Besi dari MP-ASI

\begin{tabular}{|c|c|c|c|c|c|c|c|}
\hline \multirow{2}{*}{$\begin{array}{c}\text { Umur } \\
\text { (bulan) }\end{array}$} & $\mathrm{n}$ & $\begin{array}{c}\text { Rerata asupan } \\
\text { zat besi per hari } \\
\text { (\% AKG) }\end{array}$ & $\mathrm{SD}$ & $\mathrm{n}$ & $\begin{array}{c}\text { Rerata asupan } \\
\text { zat besi per hari } \\
\text { (\% AKG) }\end{array}$ & $\mathrm{SD}$ & $\mathrm{p}$ \\
\hline 6 & 49 & - & - & 45 & - & - & \\
7 & 49 & 22,9 & 6,02 & 45 & 28,4 & 5,78 & \\
8 & 49 & 23,2 & 7,03 & 45 & 28,8 & 6,04 & 0,881 \\
9 & 49 & 31,4 & 6,9 & 45 & 39,2 & 9,50 & 0,129 \\
10 & 49 & 29,3 & 9,9 & 45 & 36,6 & 11,89 & 0,549 \\
11 & 49 & 39,2 & 12,0 & 45 & 45,2 & 17,82 & 0,819 \\
\hline
\end{tabular}

Tabel 6

Rerata Jumlah Episode Diare Bayi per Bulan

\begin{tabular}{|c|c|c|c|c|c|c|c|}
\hline \multirow{2}{*}{$\begin{array}{l}\text { Umur } \\
\text { (bulan) }\end{array}$} & \multicolumn{3}{|c|}{ FT } & \multicolumn{3}{|c|}{ FBT } & \multirow[b]{2}{*}{$p$} \\
\hline & $\mathrm{n}$ & $\begin{array}{l}\text { Rerata jumlah } \\
\text { episode (kali) }\end{array}$ & SD & $\mathrm{n}$ & $\begin{array}{l}\text { Rerata jumlah } \\
\text { episode (kali) }\end{array}$ & SD & \\
\hline 6 & 49 & 0,24 & 0,434 & 45 & 0,27 & 0,495 & \\
\hline 7 & 49 & 0,57 & 0,791 & 45 & 0,53 & 0,757 & 0,715 \\
\hline 8 & 49 & 0,49 & 0,739 & 45 & 0,60 & 0,780 & 0,481 \\
\hline 9 & 49 & 0,43 & 0,764 & 45 & 0,40 & 0,654 & 0,993 \\
\hline 10 & 49 & 0,57 & 0,957 & 45 & 0,56 & 0,693 & 0,865 \\
\hline 11 & 49 & 0,65 & 0,694 & 45 & 0,44 & 0,624 & 0,095 \\
\hline
\end{tabular}

Dari tabel 7 terlihat bahwa selama 5 bulan perlakuan, kelompok FT mengalami diare rerata 2,88 kali, sedangkan pada kelompok FT mengalami diare sebanyak 2,80 kali. Kejadian diare setiap bulan pada kedua kelompok cenderung sama, dan uji GLM Repeated Measure Analysis of Covariance menunjukkan tidak ada perbedaan bermakna $(p>0,05)$ kumulatif rerata jumlah episode diare antar kelompok.

Tabel 7

Kumulatif Rerata Jumlah Episode Diare per Bulan

\begin{tabular}{|c|c|c|c|c|c|c|c|}
\hline \multirow{2}{*}{$\begin{array}{c}\text { Umur } \\
\text { (bulan) }\end{array}$} & $\mathrm{n}$ & $\begin{array}{c}\text { Kumulatif rerata } \\
\text { jumlah episode } \\
\text { (kali) }\end{array}$ & $\mathrm{SD}$ & $\mathrm{n}$ & $\begin{array}{c}\text { Kumulatif rerata } \\
\text { jumlah episode } \\
\text { (kali) }\end{array}$ & $\mathrm{SD}$ & $\mathrm{p}$ \\
\hline 6 & 49 & 0,24 & 0,434 & 45 & 0,27 & 0,495 & \\
7 & 49 & 0,82 & 0,993 & 45 & 0,80 & 1,013 & 0,812 \\
8 & 49 & 1,31 & 1,372 & 45 & 1,40 & 1,404 & 0,636 \\
9 & 49 & 1,67 & 1,725 & 45 & 1,80 & 1,604 & 0,656 \\
10 & 49 & 2,22 & 2,329 & 45 & 2,36 & 1,884 & 0,786 \\
11 & 49 & 2,88 & 2,658 & 45 & 2,80 & 2,095 & 0,603 \\
\hline
\end{tabular}


Lama diare adalah hari kejadian diare yang dicatat per kejadian diare. Lama diare dapat digunakan untuk menggambarkan tingkat keparahan diare yang dialami oleh bayi. Lama hari diare yang dialami oleh bayi selama intervensi MP-ASI juga meningkat dibandingkan dengan data dasar (Tabel 8). Uji GLM Repeated Measure Analysis of Covariance menunjukkan bahwa perbedaan rerata lama diare pada bayi umur 11 bulan tidak bermakna $(p>0.05)$.

Tabel 8

Rerata Lama Diare

\begin{tabular}{|c|c|c|c|c|c|c|c|}
\hline \multirow{2}{*}{$\begin{array}{c}\text { Umur } \\
\text { (bulan) }\end{array}$} & \multicolumn{3}{|c|}{$\mathrm{FT}$} & \multicolumn{3}{|c|}{ FBT } & \multirow{2}{*}{$\mathrm{n}$} \\
\cline { 2 - 7 } & $\mathrm{n}$ & $\begin{array}{c}\text { Lama diare } \\
\text { per bayi (hari) }\end{array}$ & $\mathrm{SD}$ & $\mathrm{n}$ & $\begin{array}{c}\text { Lama diare } \\
\text { per bayi (hari) }\end{array}$ & $\mathrm{SD}$ & $\mathrm{P}$ \\
\hline 6 & 49 & 0,63 & 1,334 & 45 & 0,89 & 2,279 & \\
7 & 49 & 1,57 & 2,598 & 45 & 1,53 & 3,012 & 0,648 \\
8 & 49 & 1,41 & 2,684 & 45 & 1,53 & 2,232 & 0,648 \\
9 & 49 & 1,10 & 2,365 & 45 & 2,02 & 3,696 & 0,220 \\
10 & 49 & 1,53 & 2,732 & 45 & 2,11 & 3,543 & 0,684 \\
11 & 49 & 2,02 & 2,634 & 45 & 1,36 & 2,347 & 0,070 \\
\hline
\end{tabular}

Jika dilihat menurut kumulatif lama diare, selama 5 bulan perlakuan kelompok FT mengalami diare sebanyak 8,27 hari sedangkan pada kelompok FBT sebanyak 9,44 hari (Tabel 9). Tidak terdapat perbedaan bermakna antara kelompok perlakuan ( $p>0,05)$, dalam hal kumulatif lama diare. Rerata lama per episode diare selama masa intervensi menggambarkan tingkat keparahan diare setiap episode yang dialami oleh bayi.
Tabel 10 menunjukkan rerata hari per episode pada bayi. Rerata lama diare per episode cenderung meningkat dibandingkan data dasar, walaupun secara statistik tidak bermakna ( $p>0,05)$. Uji statistik GLM Repeated Measures Analysis of Covariance menunjukkan bahwa secara keseluruhan perbedaan lama diare per episode pada kedua kelompok perlakuan tidak bermakna $(p>0,05)$

Tabel 9

Kumulatif Rerata Lama Diare

\begin{tabular}{|c|c|c|c|c|c|c|c|}
\hline \multirow{2}{*}{$\begin{array}{c}\text { Umur } \\
\text { (bulan) }\end{array}$} & \multicolumn{3}{|c|}{ FT } & \multicolumn{3}{|c|}{ FBT } & \multirow{2}{*}{$\mathrm{n}$} \\
\cline { 2 - 6 } & $\mathrm{n}$ & $\begin{array}{c}\text { Kumulatif lama } \\
\text { diare bayi (hari) }\end{array}$ & $\mathrm{SD}$ & $\mathrm{n}$ & $\begin{array}{c}\text { Kumulatif lama } \\
\text { diare bayi (hari) }\end{array}$ & $\mathrm{SD}$ & $\mathrm{p}$ \\
\hline 6 & 49 & 0,63 & 1,334 & 45 & 0,89 & 2,279 & \\
7 & 49 & 2,20 & 3,007 & 45 & 2,42 & 4,131 & 0,948 \\
8 & 49 & 3,61 & 4,348 & 45 & 3,96 & 4,753 & 0,863 \\
9 & 49 & 4,71 & 5,492 & 45 & 5,98 & 6,405 & 0,231 \\
10 & 49 & 6,24 & 6,921 & 45 & 8,09 & 7,818 & 0,192 \\
11 & 49 & 8,27 & 8,047 & 45 & 9,44 & 8,120 & 0,691 \\
\hline
\end{tabular}


Tabel 10

Rerata Lama Diare per Episode Diare

\begin{tabular}{|c|c|c|c|c|c|c|c|}
\hline \multirow{2}{*}{$\begin{array}{c}\text { Umur } \\
\text { (bulan) }\end{array}$} & \multicolumn{3}{|c|}{$\mathrm{FT}$} & \multicolumn{3}{|c|}{ FBT } & \multirow{2}{*}{$\mathrm{n}$} \\
\cline { 2 - 7 } & $\mathrm{n}$ & $\begin{array}{c}\text { Rerata lama (hari) } \\
\text { per episode }\end{array}$ & $\mathrm{SD}$ & $\mathrm{n}$ & $\begin{array}{c}\text { Rerata lama (hari) } \\
\text { per episode }\end{array}$ & $\mathrm{SD}$ & $\mathrm{p}$ \\
\hline 6 & 49 & 0,63 & 1,333 & 45 & 0,76 & 1,720 & \\
7 & 49 & 1,05 & 1,483 & 45 & 1,00 & 1,638 & 0,666 \\
8 & 49 & 0,92 & 1,477 & 45 & 1,17 & 1,634 & 0,569 \\
9 & 49 & 0,80 & 1,630 & 45 & 1,63 & 3,055 & 0,145 \\
10 & 49 & 1,08 & 1,855 & 45 & 1,52 & 2,121 & 0,732 \\
11 & 49 & 1,62 & 1,999 & 45 & 1,14 & 1,988 & 0,070 \\
\hline
\end{tabular}

Aktivitas fisik bayi diukur selama 1 jam pada pagi dan 1 jam pada sore hari. Terdapat 17 jenis aktivitas fisik (kemudian digolongkan menjadi 3 kelompok aktivitas, yaitu ringan, sedang dan berat). Total lama aktivitas fisik merupakan penjumlahan seluruh lama aktivitas fisik ringan, sedang dan berat selama pengamatan. Total lama aktivitas fisik bayi dapat dilihat pada Tabel 11.

Tabel 11

Total Lama Aktivitas Fisik per Hari

\begin{tabular}{|c|c|c|c|c|c|c|c|}
\hline \multirow{2}{*}{$\begin{array}{l}\text { Umur } \\
\text { (bulan) }\end{array}$} & \multicolumn{3}{|c|}{ FT } & \multicolumn{3}{|c|}{ FBT } & \multirow[b]{2}{*}{$p$} \\
\hline & $n$ & $\begin{array}{l}\text { Rerata total lama } \\
\text { aktivitas fisik (detik) }\end{array}$ & SD & $\mathrm{n}$ & $\begin{array}{l}\text { Rerata total lama } \\
\text { aktivitas fisik (detik) }\end{array}$ & SD & \\
\hline 6 & 49 & 7.183 & 354 & 45 & 7.208 & 339 & \\
\hline 7 & 49 & 7.245 & 380 & 45 & 7.327 & 99 & 0,520 \\
\hline 8 & 49 & 7.118 & 1.075 & 45 & 7.329 & 88 & 0,321 \\
\hline 9 & 49 & 7.324 & 88 & 45 & 7.313 & 257 & 0,139 \\
\hline 10 & 49 & 7.350 & 51 & 45 & 7.360 & 44 & 0,210 \\
\hline 11 & 49 & 7.401 & 552 & 45 & 7.341 & 48 & 0,188 \\
\hline
\end{tabular}

Pada kedua kelompok, total lama aktivitas fisik bayi cenderung mengalami kenaikan dari bulan ke bulan. Pada kelompok FT total lama aktivitas fisik ringan, sedang dan berat bayi umur 6 bulan sebesar 7.183 dan meningkat menjadi 7.401 pada umur 11 bulan. Pola kenaikan total lama aktivitas fisik kelompok FBT juga tidak berbeda yaitu dari 7.208 pada usia 6 bulan menjadi 7.341 detik pada umur 11 bulan. Tidak ada perbedaan yang bermakna secara statistik pada total lama aktivitas fisik antara kedua kelompok perlakuan $(p>0,05)$

Skor aktivitas fisik merupakan perkalian antara nilai suatu aktivitas fisik (terdapat 17 aktivitas dan masing-masing memiliki nilai yang ditetapkan) dengan lama aktivitas (detik). Total skor aktivitas fisik merupakan penjumlahan seluruh skor aktivitas ringan, sedang dan berat, yaitu menyatakan keseluruhan tingkat/ jenis aktivitas serta lama aktivitas itu dilakukan (Tabel 12).

Pada Tabel 12 terlihat bahwa terdapat kenaikan total skor aktivitas fisik pada kedua kelompok dari bulan ke bulan. Pada umur 6 bulan, skor total pada kelompok FT sebesar 11.948 dan pada kelompok FBT sebesar 11.982. Skor ini meningkat dan pada umur 11 bulan masing-masing menjadi 12.528 dan 12.767. Peningkatan ini terutama disebabkan bergesernya aktivitas fisik dari aktivitas fisik ringan ke aktivitas fisik berat. Secara statistik 
Gizi Indon 2007,30(2):73-97 Pengaruh pemberian makanan Arum

Atmawikarta

perubahan skor tersebut pada kedua

kelompok tidak berbeda bermakna $(p>0,05)$.

Tabel 12

Total Skor Aktifitas Fisik (Ringan, Sedang, Berat)

\begin{tabular}{|c|c|c|c|c|c|c|c|}
\hline \multirow{2}{*}{$\begin{array}{c}\text { Umur } \\
\text { (bulan) }\end{array}$} & \multicolumn{3}{|c|}{ FT } & \multicolumn{3}{|c|}{ FBT } & \\
\cline { 2 - 6 } & $\mathrm{n}$ & $\begin{array}{c}\text { Rerata total } \\
\text { skor aktivitas fisik }\end{array}$ & $\mathrm{SD}$ & $\mathrm{n}$ & $\begin{array}{c}\text { Rerata total } \\
\text { skor aktivitas fisik }\end{array}$ & $\mathrm{SD}$ & $\mathrm{p}$ \\
\hline 6 & 49 & 11.948 & 1.695 & 45 & 11.982 & 1.700 & \\
7 & 49 & 12.080 & 1.606 & 45 & 12.456 & 2.030 & 0,423 \\
8 & 49 & 12.379 & 1.574 & 45 & 12.492 & 1.442 & 0,740 \\
9 & 49 & 12.553 & 1.414 & 45 & 12.937 & 1.589 & 0,526 \\
10 & 49 & 12.529 & 1.648 & 45 & 12.520 & 1.320 & 0,479 \\
11 & 49 & 12.528 & 1.648 & 45 & 12.767 & 1.236 & 0,858 \\
\hline
\end{tabular}

Tabel 13

Perkembangan Gerak Motorik Kasar Yang Dicapai Bayi

\begin{tabular}{|c|c|c|c|c|}
\hline \multirow[b]{2}{*}{$\begin{array}{l}\text { Umur } \\
\text { (bulan) }\end{array}$} & \multirow[b]{2}{*}{ Jenis Gerakan } & FT $(n=49)$ & FBT $(n=45)$ & \multirow[b]{2}{*}{$p$} \\
\hline & & $\begin{array}{c}\text { Jumlah bayi yang } \\
\text { pertama kali melakukan } \\
\text { gerakan (\%) }\end{array}$ & $\begin{array}{c}\text { Jumlah bayi yang } \\
\text { pertama kali melakukan } \\
\text { gerakan (\%) }\end{array}$ & \\
\hline \multirow[t]{3}{*}{6} & Gerakan dasar & 40,8 & 44,4 & \multirow{3}{*}{0,722} \\
\hline & Gerakan dengan bantuan & 59,2 & 55,6 & \\
\hline & Gerakan mandiri & 0 & 0 & \\
\hline \multirow[t]{3}{*}{7} & Gerakan dasar & 24,5 & 17,8 & \multirow{3}{*}{0,427} \\
\hline & Gerakan dengan bantuan & 75,5 & 87,2 & \\
\hline & Gerakan mandiri & 0 & 0 & \\
\hline \multirow[t]{3}{*}{8} & Gerakan dasar & 10,2 & 4,4 & \multirow{3}{*}{0,347} \\
\hline & Gerakan dengan bantuan & 87,8 & 95,6 & \\
\hline & Gerakan mandiri & 2,0 & 1,1 & \\
\hline \multirow[t]{3}{*}{9} & Gerakan dasar & 4,1 & 0 & \multirow{3}{*}{0,327} \\
\hline & Gerakan dengan bantuan & 83,7 & 91,1 & \\
\hline & Gerakan mandiri & 12,2 & 8,9 & \\
\hline \multirow[t]{3}{*}{10} & Gerakan dasar & 0 & 0 & \multirow{3}{*}{0,281} \\
\hline & Gerakan dengan bantuan & 75,5 & 84,4 & \\
\hline & Gerakan mandiri & 24,5 & 15,6 & \\
\hline \multirow[t]{3}{*}{11} & Gerakan dasar & 0 & 0 & \multirow{3}{*}{0,965} \\
\hline & Gerakan dengan bantuan & 55,1 & 55,6 & \\
\hline & Gerakan mandiri & 44,9 & 44,4 & \\
\hline
\end{tabular}

Perkembangan motorik adalah kemampuan gerak motorik kasar bayi dengan berpedoman pada 17 macam gerak. Pada penelitian ini ke-17 gerak motorik kasar tersebut dikelompokkan ke dalam tiga kelompok, yaitu, gerakan dasar, gerakan dengan bantuan dan gerakan mandiri.
Perkembangan gerak motorik kasar sampel dapat dilihat pada Tabel 13. Pada umur 6 bulan (baseline), sebagian besar bayi baru mampu melakukan kegiatan gerakan dasar namun sudah ada bayi yang mampu melakukan gerakan dasar dan gerakan dengan bantuan pada kedua kelompok. 
Gizi Indon 2007,30(2):73-97 Pengaruh pemberian makanan Arum

Atmawikarta

Persentase bayi yang melakukan gerakan dasar terus mengalami penurunan, sementara gerakan dengan bantuan mengalami kenaikan. Pada umur 10 bulan, sudah tidak ada lagi bayi yang hanya mampu melakukan kegiatan gerak dasar. Uji statistik chi-square menunjukkan bahwa tidak ada perbedaan bermakna perkembangan gerak motorik kasar antara kedua kelompok $(p>0,05)$.

Pertumbuhan dilakukan dengan mengukur perkembangan berat badan dan panjang badan bayi menurut umur (BB/U, $\mathrm{PB} / \mathrm{U}$, dan $\mathrm{BB} / \mathrm{PB}$ ) menurut kelompok perlakuan. Pada tabel 14 disajikan hasil pertumbuhan berdasarkan $\mathrm{BB} / \mathrm{PB}$ saja berdasarkan rerata z-score. Selama 5 bulan perlakuan, nilai z-score pada kelompok FT maupun FBT mengalami penurunan, atau dapat dikatakan kedua kelompok menunjukkan perbaikan pertumbuhan. Pada kelompok FT terjadi pertumbuhan 0,68 unit dan pada kelompok FBT terjadi pertumbuhan 0,83 unit. Jelasnya pada gambar 2 dapat dilihat kecenderungan pertumbuhan pada kedua kelompok. Uji statistik GLM Repeated Measure-Analysis of Covariance menunjukkan perbedaan perbaikan nilai z-score pada kedua kelompok tersebut tidak bermakna $(p>0,05)$

Tabel 14

Rerata Z-score Berat Badan Menurut Panjang Badan (BB/PB)

\begin{tabular}{|cccccccc|}
\hline $\begin{array}{c}\text { Umur } \\
\text { (bulan) }\end{array}$ & $\mathrm{n}$ & $\begin{array}{c}\text { Rerata } \\
\text { Z-score BB/PB }\end{array}$ & SD & $\mathrm{n}$ & $\begin{array}{c}\text { Rerata } \\
\text { Z-score BB/PB }\end{array}$ & SD & $\mathrm{p}$ \\
\cline { 2 - 6 } & 49 & $-0,13$ & 0,752 & 45 & 0,13 & 0,683 & \\
7 & 49 & $-0,32$ & 0,830 & 45 & $-0,08$ & 0,699 & 0,775 \\
8 & 49 & $-0,53$ & 0,772 & 45 & $-0,29$ & 0,648 & 0,775 \\
9 & 49 & $-0,64$ & 0,750 & 45 & $-0,42$ & 0,584 & 0,725 \\
10 & 49 & $-0,72$ & 0,744 & 45 & $-0,62$ & 0,757 & 0,085 \\
11 & 49 & $-0,81$ & 0,803 & 45 & -0.70 & 0,757 & 0,162 \\
\hline
\end{tabular}

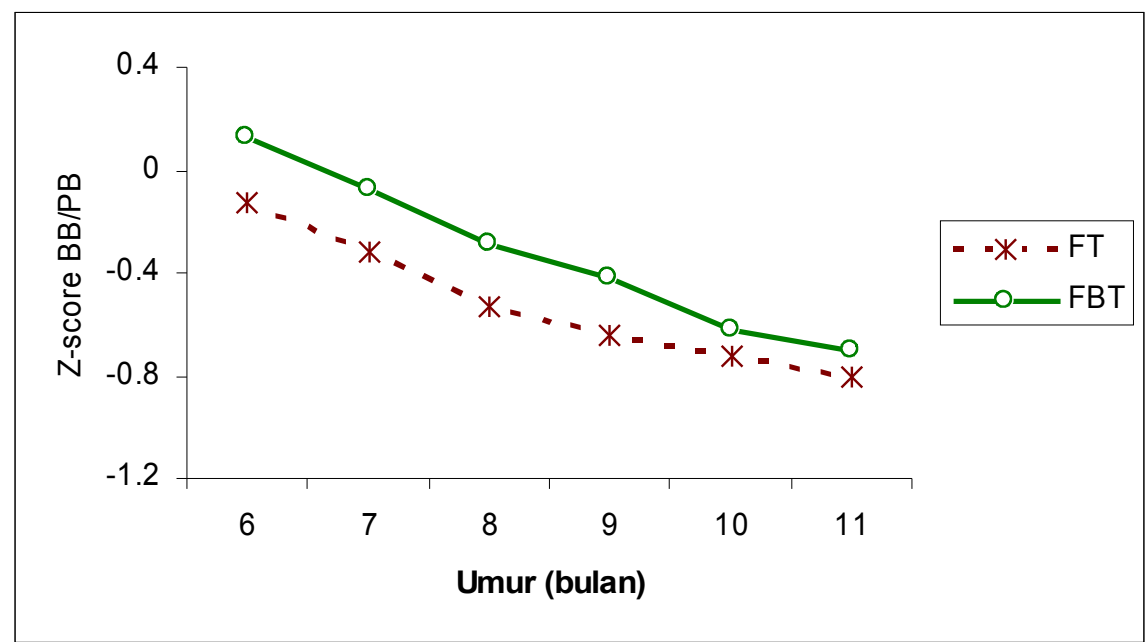

Gambar 2

Kecenderungan Perubahan Rerata Z-score BB/PB 
Gizi Indon 2007,30(2):73-97 Pengaruh pemberian makanan Arum

Atmawikarta

Kadar vitamin A dalam darah diukur dengan metode Liquid-Chromathographic Assay. Pada Tabel 15 dapat dilihat bahwa baik pada kelompok FT maupun pada kelompok FBT terjadi penurunan kadar vitamin A dalam darah. Dengan menggunakan uji-t, rerata penurunan kadar vitamin $A$ dalam darah antara kelompok FT dan kelompok FBT secara statistik tidak bermakna $(p>0.05)$. Dengan menggunakan standar kadar normal vitamin A dalam darah menurut $\mathrm{WHO}$ sebesar $\geq 20 \mu \mathrm{g} / \mathrm{dL}$, maka rerata kadar vitamin A pada kedua kelompok termasuk dalam batas normal.

Tabel 15

Kadar Vitamin A pada Kelompok FT dan FBT

\begin{tabular}{|c|c|c|c|c|c|c|c|}
\hline \multirow{2}{*}{$\begin{array}{c}\text { Umur } \\
(\text { bulan) }\end{array}$} & \multicolumn{3}{|c|}{$\mathrm{FT}$} & \multicolumn{3}{|c|}{ FBT } & \multirow{2}{*}{$\mathrm{p}$} \\
\cline { 2 - 7 } & $\mathrm{n}$ & $\begin{array}{c}\text { Rerata vitamin A } \\
(\mu \mathrm{g} / \mathrm{dL})\end{array}$ & $\mathrm{SD}$ & $\mathrm{n}$ & $\begin{array}{c}\text { Rerata vitamin A } \\
(\mathrm{ug} / \mathrm{dL})\end{array}$ & $\mathrm{SD}$ & \\
\hline 6 & 43 & 26,32 & 7.48 & 33 & 25,46 & 6,34 & \\
11 & 43 & 23,40 & 5.22 & 33 & 21,89 & 5,52 & \\
Perubahan & & $-2,92$ & & & -3.57 & & 0,755 \\
\hline
\end{tabular}

Kadar Hemoglobin $(\mathrm{Hb})$ diukur dari darah yang diambil dari bayi yang menjadi sampel dengan menggunakan metode Cyanmeth. Kadar $\mathrm{Hb}$ dapat dijadikan sebagai proxy indicator untuk mengukur status zat gizi mikro pada bayi. Pada Tabel 16 tampak adanya kenaikan kadar $\mathrm{Hb}$ baik pada kelompok FT maupun pada kelompok FBT. Uji-t menunjukkan bahwa perbedaan kenaikan kadar $\mathrm{Hb}$ antar kedua kelompok tidak berbeda secara bermakna $(p>0,05)$.

Tabel 16

Kadar $\mathrm{Hb}$ pada Kelompok FT dan FBT

\begin{tabular}{|c|c|c|c|c|c|c|c|}
\hline \multirow{2}{*}{$\begin{array}{c}\text { Umur } \\
\text { (bulan) }\end{array}$} & \multicolumn{3}{|c|}{$\mathrm{FT}$} & \multicolumn{3}{|c|}{ FBT } & \multirow{2}{*}{$\mathrm{p}$} \\
\cline { 2 - 7 } & $\mathrm{n}$ & $\begin{array}{c}\text { Rerata Hb } \\
(\mathrm{g} / \mathrm{dL})\end{array}$ & $\mathrm{SD}$ & $\mathrm{n}$ & $\begin{array}{c}\text { Rerata Hb } \\
(\mathrm{g} / \mathrm{dL})\end{array}$ & $\mathrm{SD}$ & 10,83 \\
\hline 6 & 46 & 10,98 & 0,91 & 42 & 1,11 & \\
11 & 46 & 11,30 & 1,00 & 42 & 11,16 & 1,13 & \\
Perubahan & & 0,32 & & & 0,33 & & 0,986 \\
\hline
\end{tabular}

Menurut kriteria WHO, kadar $\mathrm{Hb}$ bayi dianggap normal pada level $11 \mathrm{~g} / \mathrm{dL}$ dan kadar $\mathrm{Hb}$ yang kurang dari level normal tersebut digolongkan ke dalam anemia. Tabel 17 menunjukkan jumlah bayi pada kedua kelompok menurut status anemia dan tidak anemia di awal dan akhir penelitian. Uji Statistik menunjukkan tidak ada perbedaan bermakna antara kedua kelompok.

Tabel 17

Jumlah Bayi dengan Status Anemia dan Tidak Anemia di Awal dan Akhir Penelitian

\begin{tabular}{|c|c|c|c|c|c|c|c|}
\hline \multirow{2}{*}{$\begin{array}{c}\text { Umur } \\
\text { (bulan) }\end{array}$} & \multicolumn{3}{|c|}{ FT } & \multicolumn{3}{c|}{ FBT } & \multirow{2}{*}{$\mathrm{n}$} \\
\cline { 2 - 7 } & Anemia & $\begin{array}{c}\text { Tidak } \\
\text { Anemia }\end{array}$ & $\mathrm{n}$ & Anemia & $\begin{array}{c}\text { Tidak } \\
\text { Anemia }\end{array}$ & $\mathrm{p}$ \\
\hline 6 & 46 & 52,2 & 47,8 & 42 & 45,2 & 54,8 & 0.317
\end{tabular}


Gizi Indon 2007,30(2):73-97 Pengaruh pemberian makanan Arum

Atmawikarta

\begin{tabular}{|l|l|l|l|l|l|l|}
\hline 11 & 46 & 34,8 & 65,2 & 42 & 45,2 & 54,8 \\
\hline
\end{tabular}

Kadar feritin dalam darah diukur menggunakan metode ELISA. Feritin merupakan cadangan zat besi yang berada pada hati, ginjal, dan sumsum tulang belakang. Feritin merupakan globulin yang diperkirakan mengandung 20 persen zat

besi. Setiap $1 \mu \mathrm{g} / \mathrm{L}$ serum feritin sebanding dengan 8-10 mg cadangan zat besi ${ }^{(9)}$. Kadar feritin merupakan indikator yang sensitif tentang status zat besi dan menggambarkan status gizi. Pada Tabel 18 tampak kenaikan kadar feritin pada kelompok FT dan FBT.

Tabel 18

Kadar Feritin pada Kelompok FT dan FBT

\begin{tabular}{|c|c|c|c|c|c|c|c|}
\hline \multirow{2}{*}{$\begin{array}{c}\text { Umur } \\
(\text { bulan) }\end{array}$} & \multicolumn{3}{|c|}{$\mathrm{FT}$} & \multicolumn{3}{|c|}{ FBT } & \multirow{2}{*}{$\mathrm{p}$} \\
\cline { 2 - 7 } & $\mathrm{n}$ & $\begin{array}{c}\text { Rerata feritin } \\
(\mu \mathrm{g} / \mathrm{L})\end{array}$ & $\mathrm{SD}$ & $\mathrm{n}$ & $\begin{array}{c}\text { Rerata feritin } \\
(\mu \mathrm{g} / \mathrm{L})\end{array}$ & $\mathrm{SD}$ & \\
\hline 6 & 39 & 38,30 & 18,29 & 38 & 39,57 & 21,13 & \\
11 & 39 & 51,94 & 18,42 & 38 & 43,35 & 18,62 & \\
Perubahan & & 13.64 & & & 3,78 & & 0.007 \\
\hline
\end{tabular}

Pada kelompok FT terjadi kenaikan rerata kadar feritin sebesar 13,64 $\mu \mathrm{g} / \mathrm{L}$, sedangkan pada kelompok FBT naik 3,78 $\mu \mathrm{g} / \mathrm{L}$. Kenaikan kadar feritin pada kelompok FT lebih besar daripada kelompok FBT. Dengan menggunakan uji-t, perbedaan kenaikan kadar feritin pada kedua kelompok secara statistik bermakna $(p<0,05)$. Dibandingkan dengan standar 10,0 $\pm 6 \mu \mathrm{g} / \mathrm{L}$ (Bender, 1997), kadar feritin dalam penelitian ini lebih tinggi.

\section{BAHASAN}

Dalam hal rentang waktu, penelitian menggunakan dua kelompok perlakuan dengan proses rekrutmen tidak pada saat yang sama, tetapi dilakukan pada rentang waktu sekitar 6 bulan untuk menyesuaikan dengan ketersediaan sampel yang usianya memenuhi syarat 6 bulan \pm 15 hari. Hal ini menyebabkan peluang yang diterima setiap anak untuk mendapatkan pajanan perubahan lingkungan fisik dan sosial karena perbedaan rentang waktu penelitian tidak benar-benar sama.

Pemilihan kecamatan dan kelurahan dilakukan dengan mempertimbangkan kemudahan dalam pemberian perlakuan, pengontrolan dan pengumpulan data serta ketersediaan petugas penelitian. Dengan demikian penelitian ini tidak didesain untuk mewakili wilayah secara luas dengan berbagai karakteristik sosial, demografis, lingkungan dan budaya masyarakat yang berbeda.

Salah satu potensi bias adalah terjadinya drop-out. Pada penelitian ini, 47 anak atau 32 persen anak mengalami dropout. Uji-t dan uji proporsi menunjukkan bahwa tidak ada perbedaan bermakna antara sampel drop-out dan sampel yang tidak drop-out dalam hal antropometri dan data sosial ekonomi dari kedua kelompok. Dengan demikian dapat dikatakan bahwa drop-out tidak menimbulkan bias dalam analisis dan pengambilan kesimpulan.

Untuk menghindari data ekstrim (outliers), dilakukan screening nilai antropometri yang ketat dan screening penyakit kronis (TB paru dan penyakit bawaan). Demikian pula halnya dengan hasil pemeriksaan zat gizi dalam darah, angkaangka ekstrim tersebut tidak disertakan dalam analisis. Untuk mencegah terjadinya data ekstrim karena kesalahan pencatatan data, dilakukan pelatihan bagi petugas lapangan, cek reliabilitas petugas, dan verifikasi data oleh supervisor. Alat ukur yang digunakan telah distandarisasi. Petugas pengukur antropometri, pengumpul 
Gizi Indon 2007,30(2):73-97 Pengaruh pemberian makanan Arum

Atmawikarta

data konsumsi, data aktifitas fisik dan gerak motor, diberi pelatihan disertai dengan tes presisi, akurasi dan reliabilitas. Untuk menghindari kesalahan sistematis dilakukan seleksi yang ketat terhadap petugas dan pilot test.

Berbagai kejadian spesifik selama masa penelitian dapat mempengaruhi penelitian sehingga berpotensi menimbulkan bias. Pada penelitian ini beberapa peubah yang dimonitor untuk menghindari terjadinya bias antara lain adalah konsumsi makanan anak selain MP-ASI, serta kepatuhan dalam mengkonsumsi MP-ASI. Peubah perancu lain adalah peubah sosial ekonomi. Hasil uji statistik chi-square menunjukkan bahwa peubah sosial ekonomi tidak menunjukkan perbedaan yang bermakna antara kelompok FT dan FBT. Dengan demikian, proses penarikan kesimpulan yang membandingkan antar kelompok perlakuan dapat dikatakan bebas dari bias karena pengaruh variasi sosial ekonomi.

Data dasar pada saat usia 6 bulan untuk antropometri (BB/PB) pada kedua kelompok tidak berbeda secara statistik, demikian pula dengan kadar zat gizi mikro dalam darah, yaitu kadar hemoglobin, feritin dan vitamin A. Dengan demikian jika dilihat dari faktor pertumbuhan dan zat gizi mikro dalam darah, maka pengacakan pada kedua kelompok juga cukup baik.

Kepatuhan (compliance) konsumsi MP. ASI baik FT maupun FBT pada penelitian ini cukup baik. Konsumsi rerata MP-ASI oleh anak mencapai perkiraan awal yaitu sekitar 80 persen pada usia 7,8 , dan 9 bulan, serta 70 persen pada usia 10 dan 11 bulan dengan rerata total sekitar 80 persen. Tingkat kepatuhan dalam penelitian ini cukup baik dibandingkan misalnya dengan misalnya penelitian Widjojo (2005) dengan kepatuhan sekitar 65 persen ${ }^{(10)}$.

Pada umumnya tingkat kepatuhan menurun yang mungkin terkait kebosanan dengan semakin seringnya anak mengkonsumsi MP-ASI. Hal ini terbukti dengan banyaknya anak yang drop-out dari penelitian karena tidak lagi mau makan MPASI. Informasi tentang kebosanan anak terhadap MP-ASI yang diberikan secara monoton ini sejalan dengan penelitian lain ${ }^{(11)}$ Di negara-negara sedang berkembang, karena terbatasnya ketersediaan pangan, pemberian MP-ASI kebanyakan kurang bervariasi sehingga menyebabkan rendahnya asupan energi. Penelitian klinik di Peru menunjukkan bahwa MP-ASI yang diberikan secara bervariasi, meningkatkan asupan energi sekitar 10 persen.

Jika anak masih diberi ASI, maka kebutuhan minimal akan energi dapat terpenuhi dari tiga sumber yaitu ASI, MP-ASI dan makanan lain yang diberikan keluarga. Karjati (1998) memperkirakan bahwa ASI memberikan kontribusi energi sebesar 330 kkal per hari pada anak usia 6-11 bulan. Dalam penelitian ini, rerata asupan energi yang berasal dari MP-ASI perlakuan pada anak usia 6-11 bulan pada kelompok FT berkisar antara 178 -304 kkal per hari atau 27-46 persen AKG, sedangkan pada kelompok FBT berkisar antara 172- 274 kkal per hari atau 26-42 persen AKG.

Jika digabungkan, asupan energi yang berasal dari MP-ASI dan makanan selain MP-ASI maka kebutuhan energi pada umur 7-11 bulan pada kelompok FT kisarannya 57- 95 persen, sedangkan pada kelompok FBT berkisar antara 59-96 persen. Dengan demikian asupan energi yang berasal dari MP-ASI perlakuan dan makanan lain di luar MP-ASI baik pada kelompok FT maupun pada kelompok FBT cukup baik bagi anak untuk memenuhi kebutuhan energi sesuai dengan AKG.

Dalam hal protein, MP-ASI FT maupun FBT yang diberikan kepada anak selama penelitian memberikan kontribusi yang relatif besar pada pemenuhan protein. Kepatuhan konsumsi MP-ASI yang cukup tinggi dan sesuai dengan perkiraan, berdampak pada asupan vitamin A dari MP-ASI yang cukup konstan selama masa penelitian. Tambahan vitamin A yang berasal dari MP-ASI berdampak pada dipertahankannya kadar vitamin $A$ dalam darah sesuai standar WHO yaitu $\geq 20$ $\mu \mathrm{g} / \mathrm{dL}$. Asupan zat besi yang berasal dari MP-ASI pada kelompok FT maupun kelompok FBT terus meningkat sejalan dengan pertambahan umur. Asupan zat besi seperti itu, diperkirakan memberi andil untuk 
mempertahankan kadar $\mathrm{Hb}$ dan feritin pada taraf normal $(\mathrm{Hb} \geq 11 \mathrm{~g} / \mathrm{dL}$, feritin $\geq 12 \mu \mathrm{g} / \mathrm{L})$.

Penelitian menunjukkan bahwa tidak ada perbedaan yang bermakna pada kedua kelompok terhadap berbagai ukuran morbiditas diare yang meliputi rerata jumlah episode diare, lama hari diare, dan lama diare per episode. Dengan demikian MP-ASI formula tempe (FT) tidak memberikan manfaat lebih baik kepada anak dalam hal pengurangan episode dan lama diare anak dibandingkan dengan MP-ASI formula bukan tempe (FBT).

Hasil penelitian ini berbeda dengan beberapa penelitian sebelumnya. Penelitian Sudigbia et al. (1985), Mahmud (1987), Soenarto (1997), Irawati (1994) dan Sudigbia (1999) menyebutkan bahwa jumlah dan lama episode diare pada kelompok yang mendapat FT lebih rendah dibandingkan dengan kelompok yang tidak mendapat formula tempe $\mathrm{e}^{(6,7,12,13,14)}$. Sudigbia (1999) menyatakan bahwa keunggulan sifat-sifat tempe sebagai oral rehidration therapy antara lain adalah kandungan protein yang tinggi termasuk delapan jenis asam amino esensial, sumber vitamin $B_{12}$, kandungan lemak jenuh dan kolesterol yang rendah, mempunyai struktur sel yang unik yang memudahkan pencernaan dan penyerapan, serta memiliki aktivitas anti bakteri dan merangsang pertumbuhan ${ }^{(7)}$. Namun perlu diperhatikan, penelitian yang menyebutkan kelebihan formula tempe untuk menurunkan diare pada umumnya dilakukan pada anak kurang gizi, dan tidak dibandingkan dengan formula kacang hijau (seperti pada penelitian ini) yang mempunyai komposisi zat gizi yang hampir sama.

Penelitian ini membuktikan bahwa formula tempe tidak menurunkan episode diare, lama diare dan keparahan. Dengan demikian, dapat disimpulkan bahwa pada bayi dengan status gizi baik dan tidak mengalami diare kronis, pemberian FT (berbasis tempe) dan FBT (berbasis kacang hijau) tidak mempunyai pengaruh yang berbeda secara bermakna terhadap jumlah episode, lama diare, dan lama diare per episode.

Secara umum tidak terdapat perbedaan antara kedua kelompok perlakuan dalam hal lama dan total skor aktivitas fisik. Mekanisme yang menyebabkan kecenderungan ini belum dapat dijelaskan. Sebagai perbandingan, penelitian di Pengalengan, menunjukkan adanya perbedaan skor aktivitas antar kategori kegiatan (ringan, sedang, berat) dapat terdeteksi setelah 2 bulan pengamatan pada kohor anak 12-18 bulan. Pada penelitian di Pengalengan formula yang digunakan juga dibedakan atas tiga katagori yaitu formula yang mengandung energi tinggi (1171 kkal), energi sedang (209 kkal), dan energi rendah (104 kkal) sehingga perbedaannya dapat terdeteksi ${ }^{(15)}$.

Pada penelitian ini kandungan energi dan zat gizi lain dalam FT maupun FBT hampir sama, yang berbeda bahan bakunya yaitu FT berbasis tempe sedangkan FBT berbasis kacang hijau karena yang akan diuji adalah unsur tempenya. Uji statistik menyimpulkan bahwa selama 5 bulan waktu penelitian tidak ada perbedaan total skor aktivitas fisik antara anak yang menerima FT dibanding dengan anak yang menerima FBT. Hal ini dapat dipahami karena untuk melakukan aktivitas, sangat tergantung kepada energi. Pada kelompok FT dan FBT, konsumsi energinya tidak berbeda, sehingga aktivitas fisiknya juga tidak berbeda.

Dengan metode Husaini (2003), pada penelitian ini terdapat satu bayi kelompok FT $(2.0 \%)$ yang terlambat perkembangan motoriknya pada usia 6 bulan. Pada usia 7 sampai 10 bulan, ada anak yang mengalami hambatan perkembangan motorik. Pada usia 11 bulan, pada kelompok FT dan FBT masing-masing terdapat satu bayi yang terlambat perkembangan motoriknya. Dengan demikian, bayi pada kelompok FT dan FBT dapat mempertahankan gerak motorik kasar sesuai dengan standar ${ }^{(16)}$.

Proporsi anak yang di bawah median perkembangan motorik pada usia 6 hingga 10 bulan berfluktuasi dari bulan ke bulan, namun pada kedua kelompok, proporsi bayi yang berada di bawah median anak sehat kurang dari 50 persen (lihat Tabel 19). Tidak terdapat perbedaan bermakna proporsi bayi yang berada di bawah median anak sehat 
Gizi Indon 2007,30(2):73-97 Pengaruh pemberian makanan Arum

Atmawikarta

pada kedua kelompok $(p>0,05)$ pada semua

umur.

Tabel 19

Proporsi Anak menurut Median

\begin{tabular}{|c|c|c|c|c|c|c|}
\hline \multirow{3}{*}{$\begin{array}{l}\text { Umur } \\
\text { (bulan) }\end{array}$} & \multirow{3}{*}{$\begin{array}{c}\text { Status sampel } \\
\text { penelitian }\end{array}$} & \multicolumn{4}{|c|}{ Proporsi sampel dibanding median } & \multirow{3}{*}{$p$} \\
\hline & & \multicolumn{2}{|c|}{$\mathrm{FT}$} & \multicolumn{2}{|c|}{ FBT } & \\
\hline & & $\mathrm{n}$ & $\%$ & $\mathrm{n}$ & $\%$ & \\
\hline 6 & $<$ median & 19 & 38.8 & 19 & 42.2 & 0.734 \\
\hline & $\geq$ median & 30 & 61.2 & 26 & 57.8 & \\
\hline 7 & $<$ median & 12 & 24.5 & 8 & 17.8 & 0.427 \\
\hline & $\geq$ median & 37 & 75.5 & 37 & 82.2 & \\
\hline 8 & $<$ median & 21 & 42.9 & 20 & 44.4 & 0.877 \\
\hline & $\geq$ median & 28 & 57.1 & 25 & 55.6 & \\
\hline 9 & $<$ median & 13 & 26.5 & 9 & 20.0 & 0.455 \\
\hline & $\geq$ median & 36 & 73.5 & 36 & 80.0 & \\
\hline 10 & $<$ median & 20 & 40.8 & 21 & 46.7 & 0.568 \\
\hline & $\geq$ median & 29 & 59.2 & 24 & 53.3 & \\
\hline 11 & $<$ median & 14 & 28.6 & 6 & 13.3 & 0.071 \\
\hline & $\geq$ median & 35 & 71.4 & 39 & 86.7 & \\
\hline
\end{tabular}

Hasil penelitian di Pangalengan menunjukkan bahwa anak usia 12 bulan yang mendapat energi dan zat gizi mikro lebih tinggi perkembangan motoriknya. Pada penelitian ini, tidak ditemukannya perbedaan bermakna gerakan motorik kasar pada kedua kelompok kemungkinan diakibatkan oleh jumlah energi yang diberikan pada kedua kelompok adalah sama. Dalam hal ini, kandungan energi dan zat gizi pada formula FT dan FBT relatif sama, demikian pula dengan total asupan energi dari MP-ASI dan makanan selain MP-ASI. Penelitian Pollitt et al. (2000) dapat mendeteksi perbedaan gerak motorik karena kandungan energi antara 3 kelompok dibedakan, yaitu kelompok energi-tinggi (1.171 kkal), energisedang (209 kkal), dan energi-rendah (104 kkal) ${ }^{(17)}$

Selain itu, pada penelitian Pollitt et al. (2000) zat besi yang ditambahkan sebesar $12 \mathrm{mg}$ atau 150 persen AKG. Pada penelitian ini kandungan zat besi pada kedua formula hanya $4,6 \mathrm{mg}$ pada $\mathrm{FT}$ dan $4,4 \mathrm{mg}$ pada FBT. Kadar zat besi tersebut sudah sesuai dengan standar SNI dan CAC, walaupun baru mencapai sekitar 64 persen AKG. Selain itu, subyek penelitian Pollitt adalah anak yang menderita kurang gizi, sehingga respon terhadap pemberian energi dan zat besi dapat dilihat pada aktivitas gerak motorik kasar ${ }^{(17)}$.

Jika dibandingkan dengan kondisi Kabupaten Bogor tahun 2004 (Gambar 3), status BB/U kelompok FT dan FBT sedikit lebih rendah, namun mempunyai pola kenaikan yang serupa. Gambar 4 menunjukkan perkembangan BB/U pada bayi laki-laki dan perempuan jika dibandingkan dengan standar terbaru BB/U WHO (2005). Secara umum dapat dikatakan bahwa status BB/U sampel lebih rendah dibandingkan dengan standar terbaru BB/U WHO baik untuk laki-laki maupun perempuan ${ }^{(18)}$. 


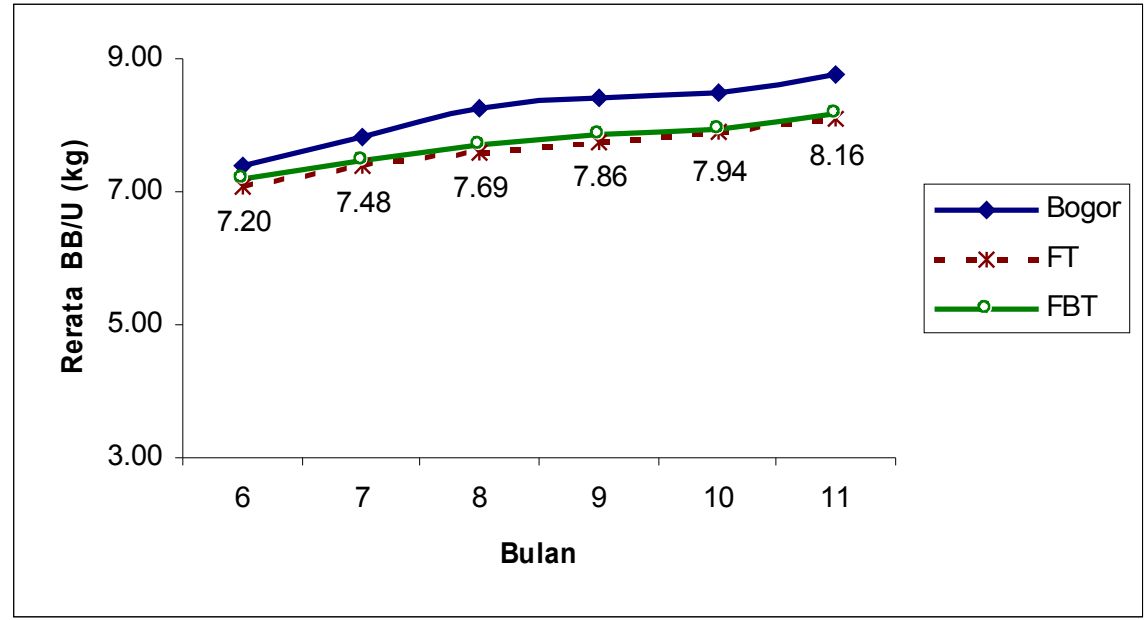

Gambar 3

Perkembangan BB/U Kelompok FT dan FBT Dibandingkan dengan Kabupaten Bogor
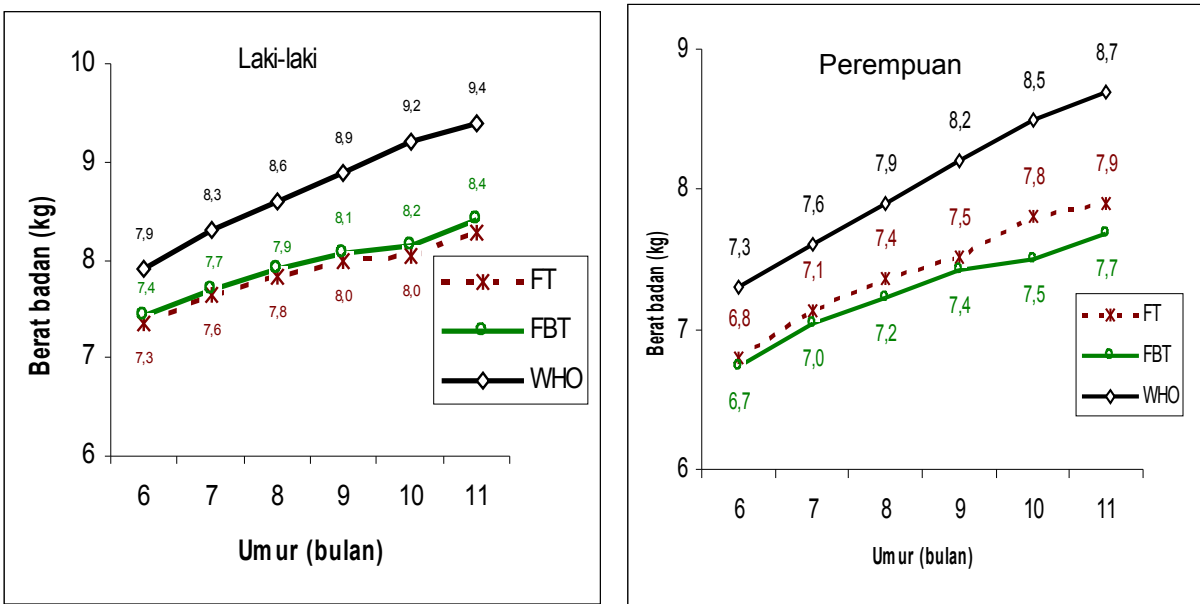

Gambar 4

Perkembangan BB/U Bayi Laki-laki dan Perempuan Dibandingkan dengan Standar WHO 2005

Jika dibandingkan dengan data Susenas 2003 dan Kabupaten Bogor 2004, pola penurunan rerata Z-score kelompok FT dan FBT mempunyai arah yang sama (Gambar 5). Hal ini menunjukkan bahwa gangguan pertumbuhan anak mulai usia 6 bulan dan seterusnya merupakan masalah yang cukup serius di Indonesia. Penurunan z-score juga tetap terjadi meskipun bayi usia 6-11 bulan dalam penelitian ini masih tetap berada dalam kategori status gizi baik (Zscore antara -2 SD dan +2 SD) dan mereka mendapatkan asupan zat gizi yang cukup baik. Hal ini sejalan dengan hasil penelitian yang dilakukan oleh Jus'at (1991), Jahari (2000), dan Schmidt (2002). Pada Gambar 6, perkembangan $\mathrm{PB} / \mathrm{U}$, jika dibandingkan dengan PB/U Kabupaten Bogor tahun 2004, terlihat bahwa garis PB/U kelompok FT, FBT maupun Kabupaten Bogor mempunyai pola yang sama dan berhimpit ${ }^{(19,20,21)}$. 
Gizi Indon 2007,30(2):73-97 Pengaruh pemberian makanan Arum Atmawikarta

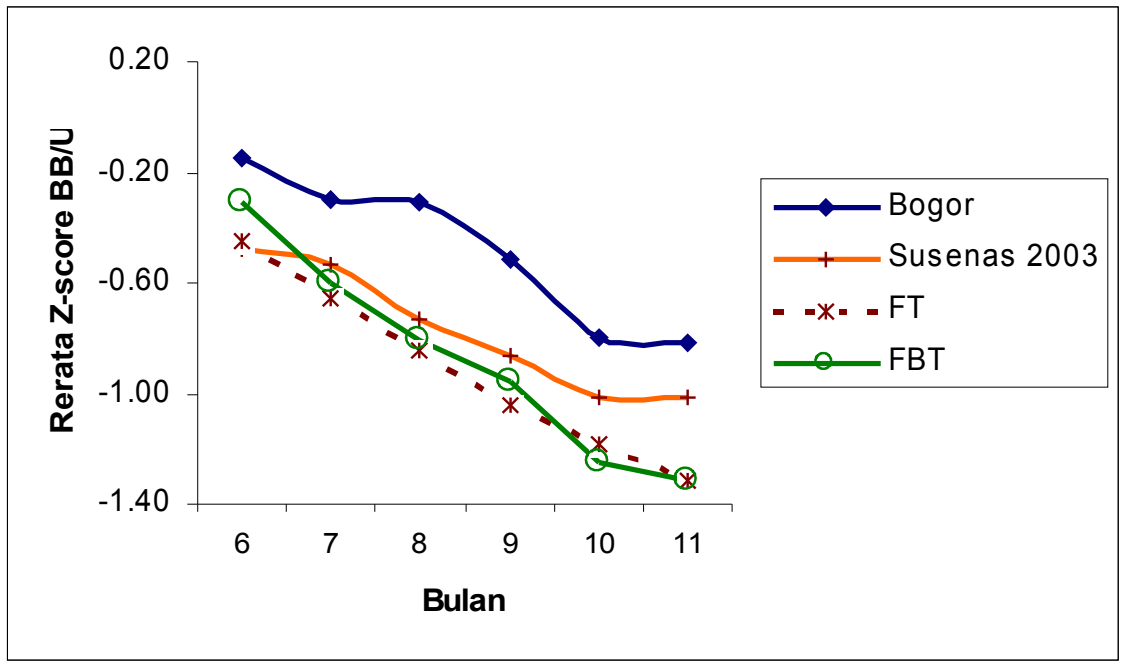

Gambar 5

Perbandingan Penurunan Z-score BB/U FT dan FBT dengan Z-score Susenas 2003 dan Kabupaten Bogor 2004

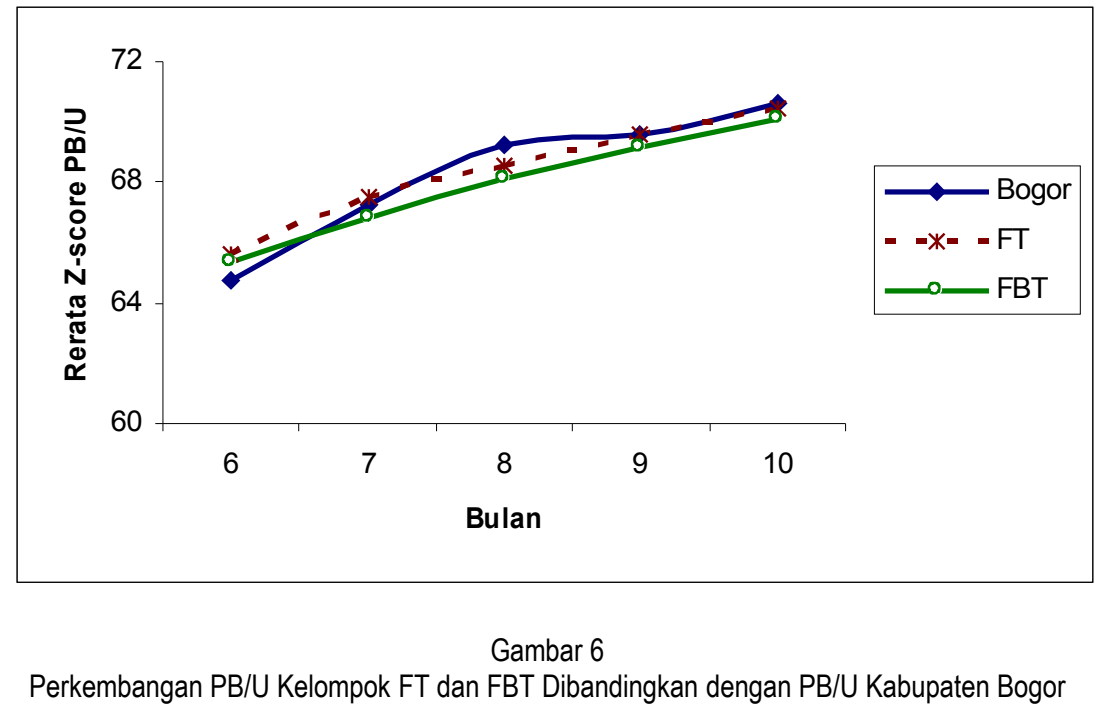

Sedangkan jika dibandingkan dengan standar $\mathrm{PB} / \mathrm{U}$ terbaru dari WHO, perkembangan $\mathrm{PB} / \mathrm{U}$ sampel penelitian baik kelompok FT maupun FBT (Gambar 7) mempunyai pola yang sama, walaupun kelompok sampel mempunyai rerata $\mathrm{PB} / \mathrm{U}$ yang lebih rendah sepanjang waktu penelitian baik pada kelompok bayi laki-laki maupu perempuan. Pola penurunan ratarata Z-score $\mathrm{PB} / \mathrm{U}$ untuk kelompok FT dan
FBT mempunyai arah yang sama dengan pola Kabupaten Bogor 2004 (Gambar 8). Hal ini menunjukkan bahwa gangguan pertumbuhan anak dilihat dari $\mathrm{PB} / \mathrm{U}$ merupakan masalah di Bogor. Dari kecenderungan di atas, walaupun z-score $\mathrm{PB} / \mathrm{U}$ FT dan FBT menurun, namun masih relatif lebih baik dibandingkan dengan kondisi umum kabupaten Bogor. 

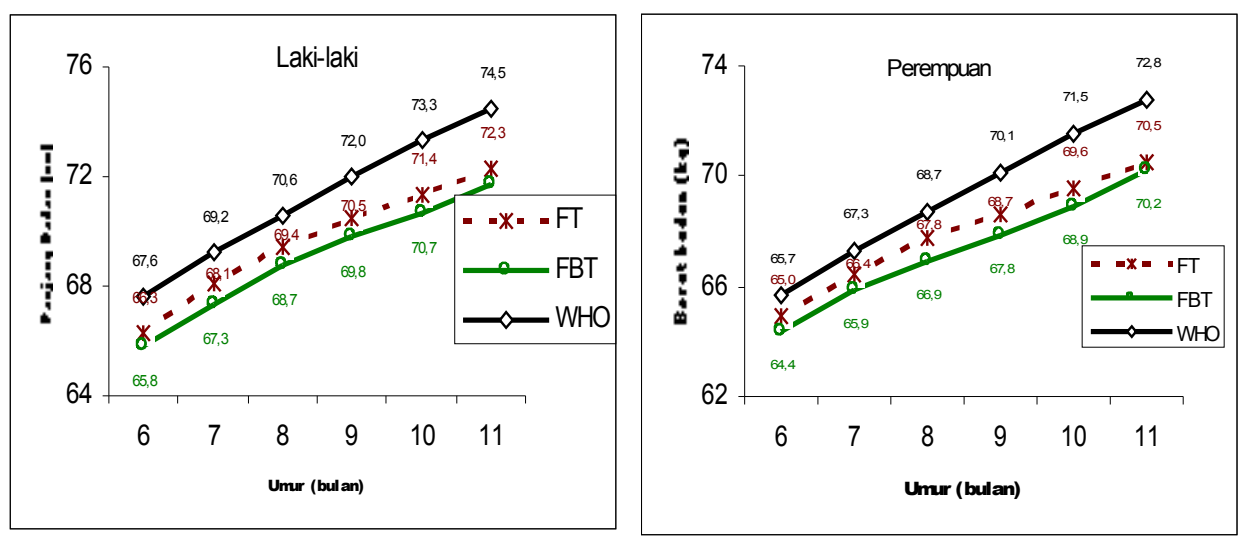

Gambar 7

Perkembangan PB/U Bayi Laki-laki dan Perempuan Dibandingkan dengan Standar WHO 2005

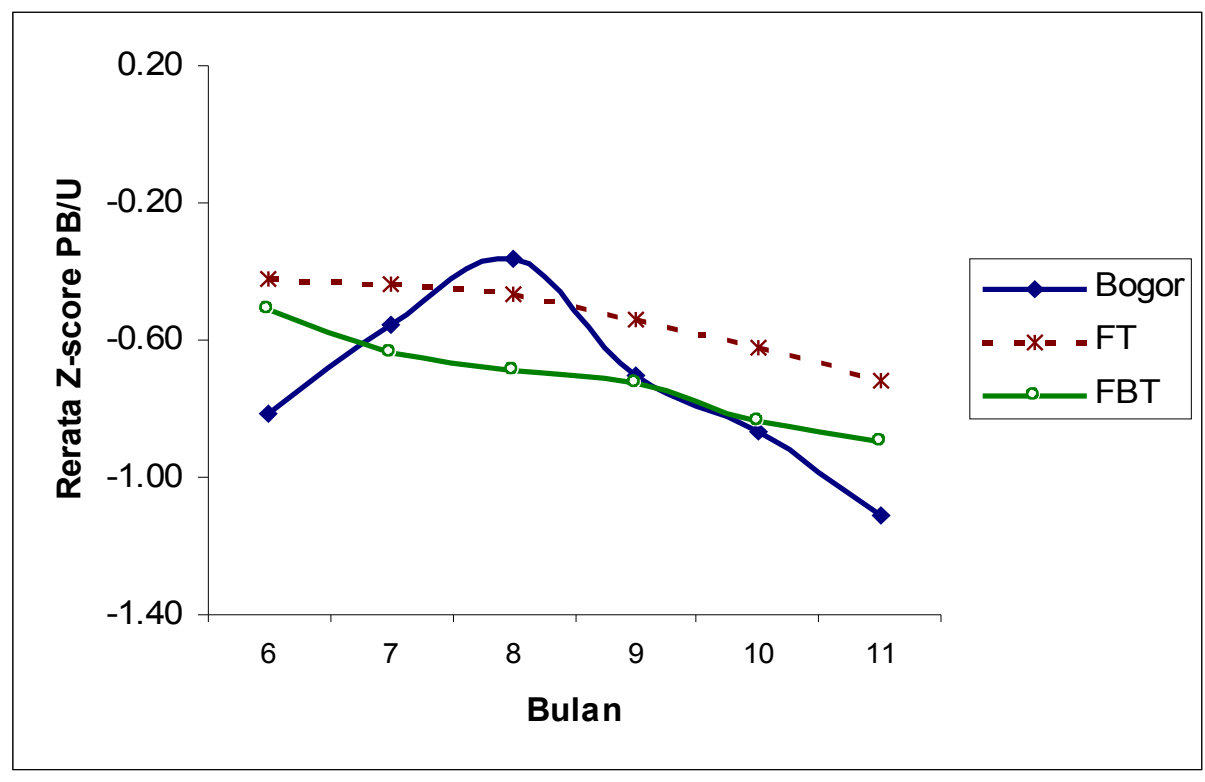

Gambar 8

Perkembangan Z-score BB/U Kelompok FT dan FBT Dibandingkan dengan Z-score Kabupaten Bogor

Gambar 9 menunjukkan perbandingan Z-score BB/PB pada sampel penelitian dengan Kabupaten Bogor. Penurunan Zscore BB/PB menunjukkan adanya penurunan status gizi yang sifatnya akut. Hal ini antara lain disebabkan adanya berbagai faktor yang menyebabkan Z-score BB/PB anak menurun misalnya asupan zat gizi yang tidak cukup atau adanya gangguan kesehatan.
Pada penelitian ini, pemberian FT pada anak tidak menyebabkan terjadinya perbedaan pertumbuhan baik yang diukur dengan Zscore BB/U, PB/U maupun BB/PB, dibandingkan dengan pemberian FBT. Hal ini dapat dipahami jika dilihat komposisi zat gizi dari kedua formula tersebut yang sebagian besar sama kandungannya, kecuali protein. Dari perhitungan asupan zat gizi terutama energi, protein, vitamin $A$, dan zat besi, di 
Gizi Indon 2007,30(2):73-97 Pengaruh pemberian makanan Arum

Atmawikarta

ketahui bahwa rerata jumlah asupan kandungan zat gizi pada kedua kelompok tidak berbeda, kecuali protein. Dengan demikian tidak adanya perbedaan pertumbuhan pada kedua kelompok kemungkinan disebabkan oleh kesamaan komposisi gizi. Sementara itu, komposisi

protein pada $\mathrm{FT}$ yang lebih tinggi, serta asupan protein pada kelompok FT yang lebih tinggi, belum cukup untuk meningkatkan pertumbuhan, karena lebih diprioritaskan untuk mendukung kebutuhan energi anak untuk melaksanakan aktifitas fisik.

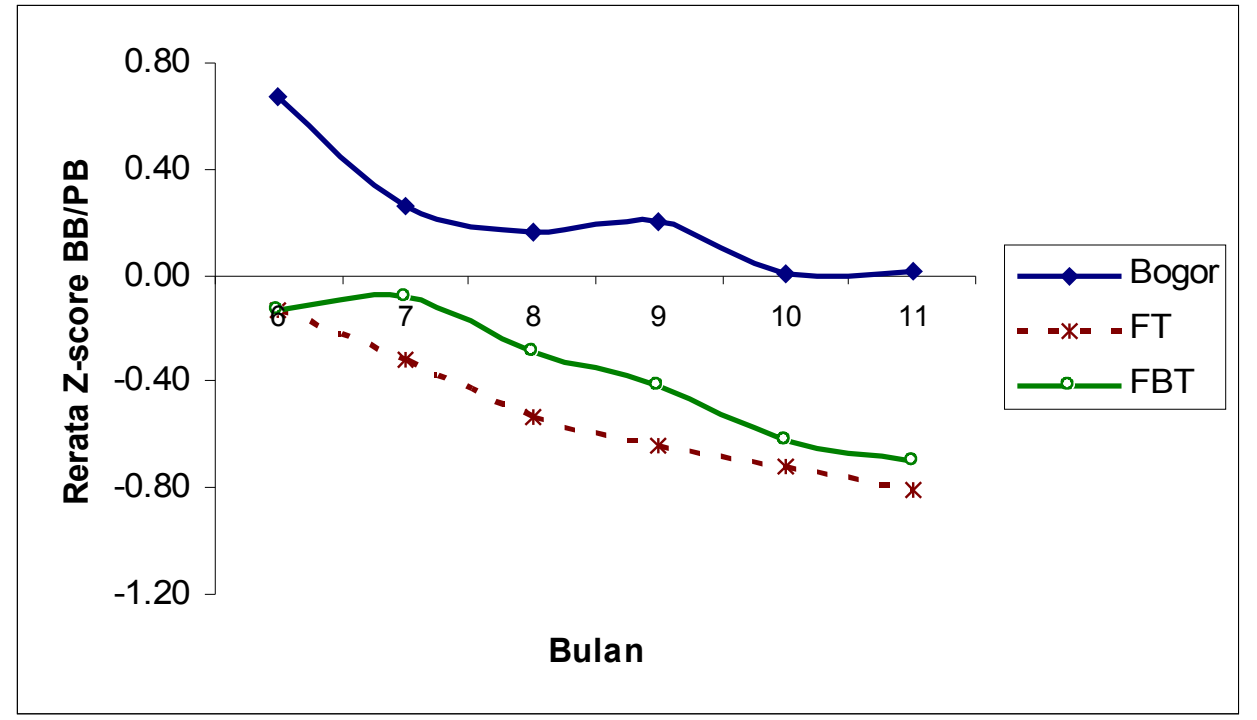

Gambar 9

Perkembangan Rerata Z-score BB/PB Kelompok FT dan FBT Dibandingkan dengan Z-score Kabupaten Bogor

Tabel 20

Perbandingan Harga Beberapa MP-ASI

\begin{tabular}{|l|c|c|c|c|c|c|c|}
\hline Jenis MP-ASI & $\begin{array}{c}\text { Kandungan } \\
\text { energi } \\
\text { per 100 g } \\
\text { (kkal) }\end{array}$ & $\begin{array}{c}\text { Kandungan } \\
\text { Protein } \\
\text { per 100 g } \\
\text { (gram) }\end{array}$ & $\begin{array}{c}\text { Berat } \\
\text { per } \\
\text { saset } \\
\text { (gram) }\end{array}$ & $\begin{array}{c}\text { Harga } \\
\text { per } \\
\text { saset } \\
(\mathrm{Rp})\end{array}$ & $\begin{array}{c}\text { Harga per } \\
\text { gram } \\
\text { MP-ASI } \\
(\mathrm{Rp})\end{array}$ & $\begin{array}{c}\text { Harga } \\
\text { per } \\
\text { kkal } \\
(\mathrm{Rp})\end{array}$ & $\begin{array}{c}\text { Harga per } \\
\text { gram } \\
\text { protein } \\
(\mathrm{Rp})\end{array}$ \\
\hline FT & 423 & 15,8 & 25 & 625 & 25,0 & 5,9 & 158,2 \\
\hline FBT & 420 & 10,7 & 25 & 625 & 25,0 & 6,0 & 233,6 \\
\hline SUN & 395,8 & 10,4 & 20 & 900 & 45,0 & 11,4 & 432,7 \\
\hline Nestle & 410 & 15 & 20 & 900 & 45,0 & 11,0 & 300,0 \\
\hline Promina & 197,9 & 14,6 & 24 & 1.000 & 41,7 & 21,1 & 285,4 \\
\hline $\begin{array}{l}\text { MP-ASI } \\
\text { Pemerintah- } \\
\text { Bubur }\end{array}$ & 410 & 17.5 & 200 & 10.000 & 50 & 12.2 & 285.7 \\
\hline $\begin{array}{l}\text { MP-ASI } \\
\text { Pemerintah }- \\
\text { Biskuit }\end{array}$ & 400 & 10 & 120 & 5.004 & 41.7 & 10.4 & 417.0 \\
\hline
\end{tabular}


Gizi Indon 2007,30(2):73-97 Pengaruh pemberian makanan Arum

Atmawikarta

MP-ASI formula tempe mempunyai keunggulan dalam hal keterjangkauan atau harga. Tabel 20 menunjukkan analisa perbedaan harga MP-ASI formula tempe (FT), formula bukan tempe (FBT), beberapa MP-ASI komersial dan MP-ASI yang digunakan dalam program pemerintah. Pada tabel tersebut dapat dilihat bahwa harga per kkal MP-ASI untuk FT sebesar Rp 5,9, dan merupakan yang termurah dibandingkan dengan MP-ASI lain yaitu FBT, MP-ASI komersial merk SUN, Nestle, Promina, dan MP-ASI program pemerintah (bubur dan biskuit). Untuk protein FT dan FBT merupakan MP-ASI dengan harga termurah yaitu $\mathrm{Rp} 158,2$ per gram protein. Dengan demikian FT dan FBT mempunyai potensi menjadi salah satu alternatif jenis MP-ASI, jika harga menjadi pertimbangan utama.

Tabel 21 memperlihatkan kecenderungan konsumsi beberapa jenis makanan yang dikonsumsi bayi. Pemberian MP-ASI komersial cenderung menurun dari bulan ke bulan, dan pada usia 10 bulan hanya sekitar 10 persen anak diberi MP-ASI komersial, sedangkan pemberian nasi tim cenderung meningkat. Walaupun persentase anak yang mengkonsumi MP-ASI komersial pada awal penelitian cukup tinggi, tetapi jumlah yang diberikan tidak cukup yaitu rerata kurang dari satu saset per hari.

Tabel 21

Persentase Anak yang Mengkonsumsi Jenis Makanan Selain MP-ASI Perlakuan Selama Masa Penelitian

\begin{tabular}{|c|c|c|c|c|c|c|c|c|c|c|}
\hline \multirow{3}{*}{ Jenis makanan } & \multicolumn{10}{|c|}{ Persentase bayi (menurut umur) yang mengkonsumi makanan } \\
\hline & \multicolumn{2}{|c|}{6} & \multicolumn{2}{|c|}{7} & \multicolumn{2}{|c|}{8} & \multicolumn{2}{|c|}{9} & \multicolumn{2}{|c|}{10} \\
\hline & FT & FBT & FT & FBT & FT & FBT & FT & FBT & FT & FBT \\
\hline Biskuit & 49 & 60 & 50 & 56 & 53 & 53 & 50 & 69 & 50 & 69 \\
\hline Bubur Nestle & 92 & 82 & 26 & 18 & 14 & 13 & 10 & 7 & 2 & 0 \\
\hline Bubur Sun & 22 & 22 & 63 & 55 & 45 & 58 & 35 & 44 & 14 & 27 \\
\hline Bubur Promina & 31 & 24 & 6 & 9 & 14 & 11 & 8 & 7 & 0 & 0 \\
\hline Bubur nasi/nasi tim & 35 & 24 & 35 & 15 & 47 & 53 & 80 & 69 & 69 & 62 \\
\hline Nasi & 0 & 0 & 0 & 0 & 2 & 0 & 2 & 9 & 18 & 15 \\
\hline Susu Kental Manis & 4 & 7 & 4 & 4 & 4 & 9 & 2 & 9 & 4 & 7 \\
\hline Susu tepung & 24 & 1 & 22 & 15 & 8 & 11 & 18 & 7 & 24 & 22 \\
\hline Pepaya & 4 & 4 & 6 & 4 & 4 & 4 & 0 & 7 & 4 & 4 \\
\hline Pisang & 12 & 15 & 14 & 4 & 14 & 15 & 12 & 29 & 26 & 22 \\
\hline Jeruk & 10 & 9 & 16 & 24 & 31 & 33 & 29 & 24 & 26 & 31 \\
\hline Wortel & 20 & 0 & 8 & 7 & 14 & 11 & 31 & 11 & 22 & 22 \\
\hline Bayam & 9 & 0 & 6 & 2 & 8 & 4 & 12 & 4 & 6 & 11 \\
\hline
\end{tabular}

Implikasi terhadap Program Perbaikan Gizi

Gangguan pertumbuhan pada bayi berusia 6-12 bulan di lokasi penelitian di Kecamatan Bogor Barat dan Kecamatan Tanah Sareal, Kota Bogor masih terjadi walaupun sudah diberikan MP-ASI yang memenuhi syarat kecukupan gizi. Kejadian ini merupakan pola pertumbuhan anak-anak Indonesia pada umumnya dan masalah gangguan pertumbuhan ini memang telah terjadi sejak lama ${ }^{(22,23)}$.

Hal ini dapat dimengerti, karena faktor penyebab terjadinya gangguan pertumbuhan bersifat kompleks, bukan hanya berkaitan dengan asupan zat gizi tetapi terkait dengan faktor-faktor lain yang lebih luas. Gizi kurang pada anak bukan semata-mata akibat kekurangan makan. Anak yang hidup pada lingkungan kecukupan pangan dan bukan berasal dari keluarga tidak miskin tetap 
Gizi Indon 2007,30(2):73-97 Pengaruh pemberian makanan Arum

memiliki kemungkinan mengalami gangguan pertumbuhan yang diukur $\mathrm{BB} / \mathrm{U}$ maupun $\mathrm{PB} /$ $U$. Beberapa penyebabnya adalah kurang memadainya praktek pemberian makanan dan pemeliharaan bayi, terbatasnya akses terhadap pelayanan kesehatan dasar, atau rendahnya sanitasi. Dengan demikian, keadaan gizi anak yang tidak baik dapat terjadi di suatu wilayah atau negara yang produksi pangannya relatif memadai ${ }^{(24)}$.

Berdasarkan Widya Karya Pangan dan Gizi Nasional, ketersediaan energi normatif direkomendasikan adalah $2.200 \mathrm{kkal} /$ orang/ hari dan ketersediaan protein adalah sebesar 57 gram/kapita/hari. Bila dibandingkan dengan rekomendasi ketersediaan energi dan protein tersebut, ketersediaan pangan nasional selama periode $2000-2005$ melebihi kebutuhan. Pada tahun 2000 bahan pangan yang tersedia mampu menyediakan energi sebesar $2.956 \mathrm{kkal} / \mathrm{kapita/hari}$ atau 34 persen lebih besar dari angka kecukupan energi. Ketersediaan protein melebihi kebutuhan yang direkomendasikan dengan kisaran 25-35 persen di atas kebutuhan pada tingkat ketersediaan. Walaupun begitu kelompok masyarakat yang mengalami defisit energi $(70 \%$ AKG) masih besar, yaitu 5,1 juta jiwa, karena terbatasnya akses ekonomi dan fisik individu/rumah tangga untuk memperoleh pangan yang cukup ${ }^{(25)}$.

Faktor penyebab lain adalah terbatasnya pengetahuan tentang pentingnya MP-ASI termasuk peranan zat gizi mikro. Pada penelitian ini, sebagian besar orangtua responden (lebih dari 60\%) berpendidikan SMP ke bawah. Tingkat pendidikan seperti itu tentu akan berpengaruh terhadap kemampuan ibu untuk memelihara kesehatan dan keadaan gizi anak $^{(22)}$. Penelitian Utomo (1996) di Indramayu, Jawa Barat menunjukkan bahwa selain faktor-faktor di atas, kepercayaan dan tatacara tradisional dalam hal pemberian MP-ASI masih terus bertahan. Kepercayaan dan alasan tradisional ini masih hidup di masyarakat, dan tidak terbatas pada orangtua bayi dan dukun bayi, tetapi dalam taraf tertentu juga hidup pada tenaga kesehatan. Oleh karena itu upaya pendidikan untuk memperbaiki pola asuh dan pemberian
MP-ASI hanya dapat dilakukan dengan upaya pendidikan yang intensif dan luas. Pada umumnya semakin tinggi upaya pendidikan semakin mudah ibu untuk memberi respon terhadap materi yang diperoleh $^{(26)}$.

Upaya jangka pendek yang dapat dilakukan adalah memberikan pendidikan gizi, pelayanan kesehatan seperti promosi ASI eksklusif, pemberian makanan tambahan, perawatan prenatal dan pelayanan kesehatan ibu dan anak, pemberian suplemen dan fortifikasi zat gizi mikro. Beberapa penelitian yang telah dilakukan di Indonesia, menunjukkan bahwa pada umumnya MP-ASI yang diproduksi di rumah tangga mempunyai kandungan zat gizi mikro yang rendah ${ }^{(27,28)}$.

Kekurangan gizi yang paling berbahaya jika hal ini terjadi pada masa kehamilan dan masa dua tahun pertama dari kehidupan anak. Efeknya akan menyebabkan gangguan kesehatan, perkembangan otak, kecerdasan, kemampuan belajar dan produktivitas yang bersifat permanen (irreversible). Beberapa bukti awal menunjukkan bahwa obesitas, penyakit kardiovaskular, dan diabetes mungkin berkaitan dengan gangguan gizi pada saat usia dini. Peluang emas (window of opportunity) untuk meningkatkan keadaan gizi anak tidak lama yaitu dari sebelum kehamilan sampai dua tahun pertama dari kehidupan anak. Dengan demikian intervensi program gizi harus dipusatkan pada masa kritis tersebut. Berbagai investasi perbaikan gizi yang dilakukan setelah melewati masa kritis tersebut akan kurang berhasil dalam meningkatkan keadaan gizi ${ }^{(24)}$.

\section{KESIMPULAN DAN SARAN}

\section{Kesimpulan}

1. MP-ASI formula tempe yang diberikan kepada bayi usia 6-11 bulan dengan status gizi baik tidak mempunyai manfaat yang lebih baik dibandingkan dengan MP-ASI formula bukan tempe (berbasis kacang hijau) dalam hal jumlah kejadian dan lama diare, 
aktivitas fisik, gerak motorik kasar, dan pertumbuhan.

2. Penelitian ini membuktikan bahwa pemberian MP-ASI formula tempe lebih bermanfaat dibandingkan dengan MP. ASI formula bukan tempe (berbasis kacang hijau) dalam meningkatkan kecukupan cadangan besi dalam darah serta mampu mempertahankan kadar $\mathrm{Hb}$ dan vitamin $\mathrm{A}$ dalam darah.

3. Pertumbuhan bayi usia $6-11$ bulan di lokasi penelitian jika dibandingkan dengan standar WHO-NCHS tahun 1983 dan standar WHO tahun 2005 mengalami gangguan pertumbuhan. Hal ini kemungkinan diakibatkan oleh status gizi yang kurang baik pada saat kehamilan dan bayi berusia 0 hingga 6 bulan.

\section{Saran}

1. Fokus upaya perbaikan gizi terutama harus diarahkan pada masa kritis yaitu antara masa terjadinya kehamilan sampai anak berusia dua tahun, untuk mencegah terjadinya hambatan perkembangan otak, kecerdasan, kemampuan belajar dan rendahnya produktivitas yang bersifat permanen (irreversible).

2. Untuk mencegah laju penurunan status gizi pada anak usia 6 bulan keatas diperlukan multi-strategi peningkatan upaya perbaikan gizi antara lain meliputi promosi ASI eksklusif, pemberian MPASI yang cukup, pelayanan prenatal, pelayanan dasar kesehatan ibu dan anak, serta suplementasi dan fortifikasi zat gizi mikro.

3. Khusus untuk masyarakat miskin yang pada umumnya mengalami permasalahan gizi yang lebih berat sehingga peluang untuk memanfaatkan windows of opportunity terbatas, pemerintah harus terus melakukan intervensi langsung untuk meningkatkan keadaan gizi pada kelompok tersebut. Di samping itu, perbaikan gizi pada kelompok miskin perlu dilakukan sebagai upaya pemenuhan hak azasi, keadilan, memberi manfaat ekomomi yang besar, dan merupakan area public good.

4. Dalam upaya peningkatan status gizi masyarakat diperlukan kemitraan antara pemerintah dan lembaga swadaya masyarakat untuk mobilisasi kemampuan masyarakat dalam mengatasi gangguan gizi melalui pendekatan pemberdayaan masyarakat.

5. Dengan pertimbangan besarnya manfaat ASI eksklusif, pemerintah bersama masyarakat, perlu semakin meningkatkan upaya cakupan ASI eksklusif, yang akhir-akhir semakin menurun, antara lain melalui promosi yang luas dan terus-menerus.

6. Disarankan kepada produsen MP-ASI komersial untuk terus bermitra dengan pemerintah dalam mengembangkan diversifikasi produk MP-ASI sehingga produk MP-ASI tersebut dapat diakses oleh berbagai strata ekonomi, dengan tetap mempertahankan kandungan zat gizi, keamanan dan harga terjangkau.

7. Diperlukan penelitian tentang efikasi, efektifitas, efisiensi serta biaya dari berbagai intervensi program perbaikan gizi yang saat ini sedang dilaksanakan oleh pemerintah, yang hasilnya dapat digunakan untuk memperbaiki alokasi dana program perbaikan gizi yang lebih baik.

8. Diperlukan penelitian dan pengembangan bentuk MP-ASI yang saat ini umumnya berbentuk bubur ke bentuk lain yang lebih bervariasi dalam hal rasa, aroma, warna, dan tekstur agar dapat diterima oleh bayi dalam rangka meningkatkan jumlah asupan MP-ASI.

\section{RUJUKAN}

1. RI-WHO. 2000. Rencana Aksi Pangan dan Gizi Nasional 2001-2005, Jakarta.

2. Badan Pusat Satatistik (BPS). 2001. Statistik Kesehatan Indonesia.

3. Lartey, A et al. 1999. A randomized, community-based trial of the effects of 
Gizi Indon 2007,30(2):73-97 Pengaruh pemberian makanan Arum

Atmawikarta

improved centrally processed complementary foods on growth and micronutrient status of Ghananian infants from 6 to 12 mo of age, Amer J. of Clin. Nutr.; I70: p.391-404.

4. WHO and UNICEF. 2003. Global Strategy for Infant and Young Child Feeding. Geneve.

5. Harahap, $\mathrm{H}$, et al. 2000. Effects of an energy and micronutrient supplement on iron deficiency anemia, physical activity and motor and mental development in undernourished children in Indonesia: European J. of Clin. Nutr, Supp.2: $114-119$.

6. Mahmud, M. K. , 1987. Penggunaan Makanan Bayi Formula Tempe Dalam Diit Bayi dan Anak Balita Sebagai Upaya Penanggulangan Masalah Diare. Disertasi Fakultas Pasca Sarjana Institut Pertanian Bogor.

7. Sudigbia, I., 1999. Tempe in the Treatment of Infant Diarrhea in Indonesia. dalam The Complete Handbook of Tempe. The Unique Fermented Soyfood of Indonesia. Published and distributed by : The American Soybean Association. p33-39.

8. Cohen, J. 1997. Statistical Power Analysis for the Behavioral Sciences. Revised Edition. Academic Press.

9. Bender A.D, Bender EA.1997. Nutrition a reference hanbook. Oxford University Press. New York, USA.

10. Widjojo, S. 2006 . Pengaruh Penambahan Frukto-Oligosakarida (FOS) pada MP-ASI terhadap Kejadian Diare dan Pertumbuhan Bayi Umur 6-12 Bulan. Disertasi Program IImu Kesehatan Masyarakat, Universitas Indonesia.

11. Underwood B,A. 1985. Weaning practices in deprived environment: The weaning dilema. Pediatricts, 75: 194198.

12. Sudigbia, I., Soemantri A., Karyadi, D., Mien, M., and Hermana. 1985. Refeeding pada Diare Kronik dengan
Makanan Tradisional. Majalah Kedokteran Indonesia No. 35. 8, dalam The Complete Handbook of Tempe. The Unique Fermented Soyfood of Indonesia. Published and distributed by : The American Soybean Association. p33-39.

13. Soenarto et al. 1997. Antidiarrheal characteristics of tempe produced traditionally and industrially in children age 6-24 months with acute diarrhea dalam Soenarti, S.Y. Diarrhea case management: Using research finding page directly for case management and teaching in a teaching hospital in Yogyakarta, Indonesia 1997 p. 99

14. Irawati, Anies dan Rossi Rozanna, 1994. Pemberian Formula Tempe pada Penderita Gizi Buruk untuk mempercepat penyembuhan. Penelitian Gizi dan Makanan jilid 17, 89-97, Pusat Penelitian dan Pengembangan Gizi.

15. Pollitt, et. al. 1997. Three-month nutritional supplementation in Indonesian infants and toddlers benefits memory function 8 year later: American $\mathrm{J}$ of Clin Nutr. 66:1357-1363)

16. Husaini, MA. et al. 2003. Studi Motor Milestone untuk Pembuatan KMS Perkembangan Anak. Pusat Penelitian dan Pengembangan Gizi dan Makanan. Badan Litbangkes RI.

17. Pollitt E, Paknawin-Mock,J, L Jarvis, $A B$ Jahari, and MA Husaini. 2000. Community-level determinants of child growth in an Indonesian tea plantation. European $\mathrm{J}$ of Clin Nutr: 54, Suppl 2, S28-S42.

18. WHO. 2006. WHO Child Growth Standards. Methods and Developments.

19. Jus'at. 1991. Determinant of Nutritional Status of Pre-school Children ini Indonesia: An Analysis of National Socio Economic Survey (SUSENAS 1987). PhD Thesis. Cornell University. New York. 
Gizi Indon 2007,30(2):73-97_ Pengaruh pemberian makanan Arum

Atmawikarta

20. Jahari AB. 2000. Status gizi balita sebelum dan selama krisis ekonomi. WNKPG VII. LIPI.

21. Schimdt $M K$ K, Muslimatun $S$, West $C E$, Schulting W, Gross R, Hautvast J G A J (2002). Nutritional status and linear growth of Indonesian in West Java are determined more by prenatal environment than postnatal factors. The American Society for Nutritional Sciences J. Nutr, 132, 2202-2207.

22. Jahari $A B$, Pollitt $C S$, Husaini MA, Pollitt E. 2000: Effect of an energy ang micronutrient supplement on motor development and motor activity in undernourished children in Indonesia, Eur J Clin Nutr 54 (Supl 2), S60-S68

23. Atmarita dan Tatang S Falah. 2003. Analisis Gizi dan Kesehatan Masyarakat, Depkes RI.

24. World Bank.2006. Repositioning Nutrition as Central to Development, A Strategy for Large-Scale Action. Washington, DC, USA.

25. Rencana Aksi Nasional Pangan dan Gizi. 2006-2010. Draft.

26. Utomo, B. 1996. Health and Social Dimensions of Infant Feeding: Lessons from Indramayu, West Java. A Doctoral Thesis. Division of Demography and Sociology, Research School of Social Sciences, The Australian National University.

27. Latief D., Atmarita, Jahari AB, Tilden R. 2000. Konsumsi pangan tingkat keluarga sebelum dan selama krisis ekonomi. Proseding Widya Karya Nasional Pangan dan Gizi VII, 2000. hal:181-192.

28. Hellen Keller International (HKI). 2002. Breatsfeeding and Complementary Feeding Practices in Indonesia. Annual Report 2002. 